\title{
Gustave Caillebotte, French Impressionism, and mere exposure
}

\author{
JAMES E. CUTTING \\ Cornell University, Ithaca, New York
}

\begin{abstract}
Gustave Caillebotte was a painter, a collector of some of his colleagues' most renowned works, and a major force in the creation of the late 19th century French Impressionist canon. Six studies are presented as a naturalistic investigation of the effects of mere exposure to images in his collection and to those matched to them. The probabilities of cultural exposure to the 132 stimulus images were indexed by the frequencies of their separate appearances in Cornell University library books-a total of 4,232 times in 980 different books. Across the studies, adult preferences were correlated with differences in image frequencies, but not with recognition, complexity, or prototypicalityjudgments; children's preferences were not correlated with frequency. Prior cultural exposure also interacted with experimental exposure in predictable ways. The results suggest that mere exposure helps to maintain an artistic canon.
\end{abstract}

\begin{abstract}
Gustave Caillebotte was Impressionism's anomaly, in his life as well as his art. ... He was 14 years younger than his initial stylistic model Degas and when his eventual close friends Monet and Renoir first began plotting an independent exhibition. . . he was still a teenager. . . . He was also rich.
\end{abstract}

$$
\text { Varnedoe (1987, p. 1) }
$$

Inheriting his father's wealth, acquired as a military supplier, Gustave Caillebotte was a rich painter at age 28 . Too young and freshly started for the first Impressionist exhibition in 1874, he was invited by Renoir to join the second in 1876, and he participated in four others. Moreover, he organized the 1876 exhibit and subsidized it and those in 1877,1879 , and 1882. Most important in this context, he also began to buy paintings in 1876, supporting his friends when little other money was coming in (see Bérhaut, 1994, Distel, 1990, Marrinan, 2002, Nord, 2000, and Varnedoe, 1987, for histories). Seven of his purchases are shown in the left-hand panels of Figures 1 and 2;

This research began as a set of interests accrued in 1993, when I was in Paris, supported by a John Simon Guggenheim Memorial Fellowship, and later, in the summer of 1994, during the Caillebotte centennial. I thank Claudia Lazzaro for being the final, if unwitting, impetus for this study in the summer of 2000 — again, in Paris — and for many wonderful hours of discussion about art and canons; Justine Zee Kwok for beginning aspects of this project as a feasibility study, for many hours of library work, and for help with initial assembly of the databases; Nicholas Epley for initial guidance through the mere exposure literature; John Bargh and Arthur Reber for encouragement and comments; Andrea Coby Riddle, the teachers, and students at the Elizabeth Ann Clune Montessori School of Ithaca for their help with Study 3; David Dunning and Dennis Regan for suggestions leading to Studies 4 and 5; and many colleagues for their friendly cajoling, forcing me to design and carry out Study 6 . A version of Study 1 was presented at the 42nd Annual Meeting of the Psychonomic Society, November 2001, in Orlando, FL. Correspondence concerning this article should be sent to J. E. Cutting, Department of Psychology, Uris Hall, Cornell University, Ithaca, NY 14853-7601 (e-mail: jec7@ cornell.edu).
Caillebotte painted Figure 1A himself. Caillebotte's major phase of acquisitions continued during the height of Impressionism. ${ }^{1}$ Aside from a few drawings, he collected only the works of Paul Cézanne, Edgar Degas, Edouard Manet, Claude Monet, Camille Pissarro, Pierre-Auguste Renoir, and Alfred Sisley. These painters are widely regarded as the "major" artists of Impressionism, and their works form the core of the Impressionist canon. ${ }^{2}$

\section{L'AFFAIRE CAILLEBOTTE}

Caillebotte died suddenly in 1894 at age 46 . His will left his entire art collection to the state of France, on the condition that the works be hung together for the public. Such a bequest was unprecedented, and the official salon culture of Paris was still ill disposed toward Impressionism. Jean-Léon Gérôme, an important salon painter who was influential in the late 19th century Paris art scene, is reported to have said, "I do not know these gentlemen and of the donation I know only the title-Are there not some paintings of Monsieur Monet in it? Of Monsieur Pissarro and others? For the state to accept such filth would be a blot on morality" (cited in Mead, 1974, unpaginated; see also Rewald, 1946, p. 422). ${ }^{3}$ But perhaps as important as the politics was the unavailability of space; there seemed to be no suitable place in Paris large enough to hang the 73 or more paintings.

The haggling went on for years, taxing the patience of Renoir, Caillebotte's executor, and Martial Caillebotte, the older brother. Eventually, the will was broken, and the collection was split, 38 images going to the state of France and the rest rejected. Two of Caillebotte's own paintings (Images 1c and 2c; see the Appendix) were included in the bequest by his family, and one Sisley (Image 60c) was later deaccessioned and sent to a regional museum. Thus, we can consider Caillebotte's Parisian legacy to be 39 works. These were first hung in 
A

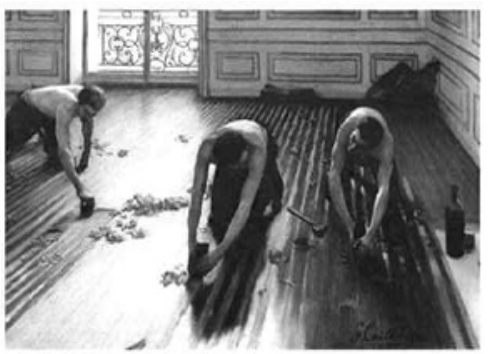

C

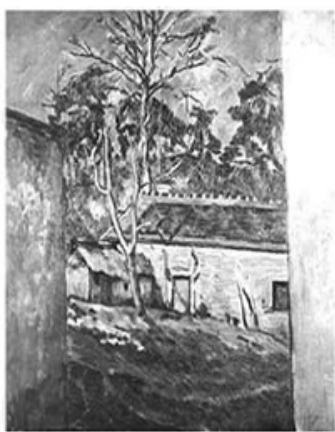

$\mathbf{E}$
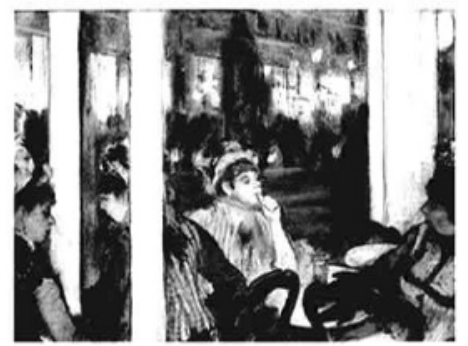

G

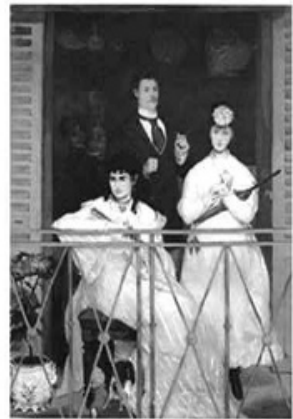

B

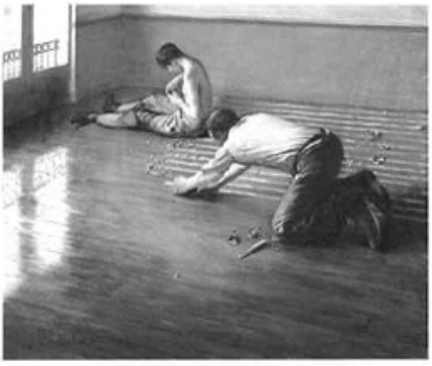

D
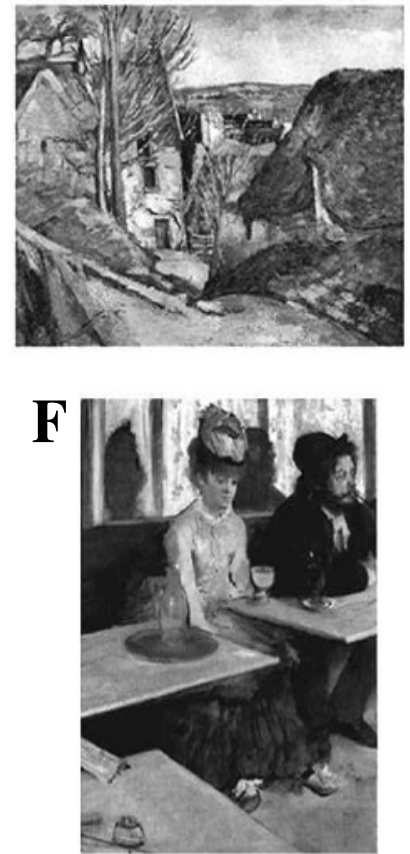

$\mathbf{H}$

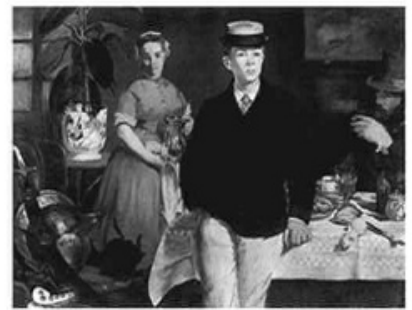

Figure 1. Eight Impressionist images. The four in the left column were part of the Caillebotte legacy to the state of France; the four on the right were matched to them for these studies. All four pairs were used as part of a corpus of 132 images. Panels A and B are Gustave Caillebotte's Les Raboteurs de parquet ("Floor scrapers," Image 1a; Paris, Musée d'Orsay) and his Les Raboteurs de parquet, petit version (Image 1n; private collection); panels C and D are Paul Cézanne's Cour de ferme à Auvers ("Auvers farmyard," Image 6c; Paris, Musée d'Orsay) and his La Maison du pendu ("Hanged man's house," Image 6n; Paris, Musée d'Orsay); panels $\mathrm{E}$ and $\mathrm{F}$ are Edgar Degas' Femmes à la terrase d'un café ("Women at the café," Image 8c; Paris, Musée du Louvre, Départment des Arts Graphiques, Fonds du Musée d'Orsay) and his L'Absinthe (“The absinthe drinker," Image 8b; Paris, Musée d'Orsay); and panels $\mathrm{G}$ and $\mathrm{H}$ are Edouard Manet's Le Balcon ('The balcony,' Image 18c; Paris, Musée d'Orsay) and his Le Déjeuner à l'atelier (“Studio luncheon,' Image 18n; Munich, Neue Pinakothek). See the Appendix for further information. Panels A, C, D, E, F, and G are reprinted with permission of the Musée d'Orsay; panel $B$ is reprinted with permission of Bridgeman Art; and panel $\mathrm{H}$ is reprinted with permission of the Neue Pinakothek. 
the Musée du Luxembourg in Paris in 1897, moved to the Musée du Louvre in 1927, then to the Musée du Jeu de Paume in 1947, and finally to the Musée d'Orsay when it opened in 1986.

Given its division of the collection, did the French government select well? According to some, very well: "With the glaring exception of Cézanne, it is arguable that [the French state] wound up with the cream of the collection" (Varnedoe, 1987, p. 202). Perhaps, but the splitting of the Caillebotte collection also offers a superb natural experiment in canon formation and fosters other questions. Nonetheless, the major focus of this article is on another issue.

\section{CANONS, CULTURE, AND MERE EXPOSURE}

An artistic canon consists of a culture's esteemed works of painting, sculpture, architecture, music, theater, poetry, literature, or film. The membership of works within a canon is graded-some are central, some less central but firmly within, some on the margins, and some clearly outside. Thus, canons have the structure of any natural category (Rosch, 1973). I assume that artworks within a canon deserve their position but also that many works on the fringes and even well outside are equally worthy and equally deserving of cultural reverence. Why are these not within the canon? I would claim that a major force in canon formation is historical accident, but I haven't the space here to defend such an idea; canon formation has been discussed at length in the humanities (e.g., Guillory, 1990, 1993; Sassoon, 2001; Hallberg, 1984). Instead, I focus here on a different issue: canon maintenance over time through its broad cultural reception.

A force that helps maintain an artistic canon, I believe, is the cultural generalization of the laboratory phenomenon called mere exposure (Zajonc, 1968, 1980), the nonconscious acquisition of information about, and attitudes toward, objects and events through their repeated presence in our lives. These occurrences help shape our preferences. Mere exposure is a phenomenon related to learning without awareness, or implicit learning (e.g., Roediger, 1990; Schacter, 1987; Seamon et al., 1995; Squire, 1992), but with a focus on the affective component. In particular, from childhood through college and throughout adulthood, we are exposed to hundreds of thousands of images. Some are representations of art; others, as during a museum visit, are the artworks themselves. We do not typically remember each occurrence of each image or where we saw it. We often will not even recognize it if we see it again, but its trace can influence our future assessments. Such assessments are not overt cognitive responses on our part. They are not directly related to the formal part of our education, but they are very much a part of our general and higher education.

The effects of mere exposure are quite automatic and independent of what we pay attention to in our day-today activities. They accrue simply as the result of being a member of a culture, experiencing cultural artifacts (see Zajonc, 1970). Laboratory evidence suggests that what we are exposed to, and then prefer, can be quite meaningless in a larger context (Bornstein, 1989)-for example, line drawings, polygons, ideographs, nonsense words or syllables, or sounds. Nonetheless, they can also be meaningful-for example, photographs of objects or people. So why not paintings? Laboratory results here are mixed. Berlyne (1970) found that there were mere exposure effects for abstract paintings but that complex ones were preferred over simpler ones. Zajonc, Shaver, Tavris, and van Kreveld (1972) found the reverse effect for abstract paintings and their parts. And Brickman, Redfield, Harrison, and Crandall (1972) found both effects, depending on initial responses, favorable or unfavorable. But as studies relying on laboratory exposure, these research efforts were not concerned with everyday exposure to artwork. The major purpose of this article, then, is to circumvent this problem-to assess effects of mere exposure as measured in a more ecological way. ${ }^{4}$

\section{GOALS}

These six studies had three goals. The first two are intertwined and were spun from the arguments above. The first concerns Caillebotte. It is sometimes suggested that he had extraordinary taste in amassing his collection (e.g., Bernac, 1895/1966). Unequivocally, some of these works are among the centerpieces of the Impressionist canon. To be sure, in many cases, he was on the scene as the first possible buyer of particular artworks, and he seems to have exercised his preferences in an optimal situation to help each friend. However, it should also be noted that many of the paintings he purchased were thought unsellable at the time he acquired them (Bazin, 1958; Rewald, 1946). Can one determine whether or not Caillebotte demonstrated exquisite taste? Through the use of paired comparisons-a major method of art historical analysis - one might have the opportunity to address such a difficult question. The second goal was to assess the role of the Musée d'Orsay in the maintenance of the Impressionist canon. Thus, we can ask with respect to contemporary viewers: Do the paintings in its collections have a special place within the Impressionist canon? If so, why?

The third goal is more pertinent to experimental and social psychology and quite incidental to both Caillebotte and the Orsay. Its focus is mere exposure as indexed by the frequency with which the images appear in print. That is, the relative frequencies of these images in books will serve as a cultural proxy; their differential number should mimic the differential likelihood that individuals will have seen these images before. The more often the images appear, the more likely it is that individuals may have seen them at least once, perhaps more. This idea is essentially the same as that proposed by Ferguson (1999), a museum curator:

Every act of writing or curatorial practice, whenever it gets to the point of naming a name, is participating in a certain level of canon formation, no matter what the intent 
of its author, no matter whether it represents a challenge to the status quo or a confirmation of it. (p. 4)

This might be modified only by adding that every act of publishing or broadcasting an image is a participation in the maintenance of, or in the change in, a canon. So I set out to enumerate particular "acts of writing or curatorial practice," needing only to choose which images to look for and a reasonable place to count them.

\section{THE IMAGES, THEIR FREQUENCIES, AND THEIR REPRESENTATIVENESS}

\section{Image Choice and Stimulus Preparation}

For the centennial of Caillebotte's death, Anne Distel, later head of the Musée d'Orsay, oversaw a celebration of his work. In Distel (1994), there are small, black-andwhite images of 65 works from the Caillebotte collection; 8 others are mentioned in brief detail without images and, sometimes, without names. Of these 73, 4 were not considered for this study-one drawing and one watercolor by Jean-François Millet, one drawing by Paul Gavarni, and one decorative fan by Camille Pissarro. From the remaining 69, at least one reasonable-quality version of 64 of the images was located -62 in books and 2 on the Internet. ${ }^{5}$ In addition, two paintings by Caillebotte himself that were eventually included in the legacy were also used.

Thus, 66 images from the Caillebotte collection were used as stimuli: 2 Caillebottes, 5 Cézannes, 8 Degas, 4 Manets, 16 Monets, 14 Pissarros, 9 Renoirs, and 8 Sisleys. These images are listed in the left column of the Appendix with their French titles and the most descriptive of their English titles. Also included are the dates they were painted (if known), their current locations (if known), and their catalogue raisonné reference numbers or, when not available, another reference citation. Among images for each artist, works are listed in their catalogue raisonné order, which is generally taken to be chronologically accurate. ${ }^{6}$ In all, 39 of these images are from the Orsay, 10 in other museums, and 17 in private collections or in locations unknown.

To begin, I sought many high-quality color reproductions of each image; 51 were found in color, 44 in at least three different printings. These were inspected for apparent consistency of reproduction, and what appeared to be the best image (or in the case of the other 7, sometimes the only image) was digitized on a LaCie Scanner III flatbed scanner. The resulting Photoshop 3.0 files were about $2 \mathrm{MB}$ in size. Such resolution approximates that of $35-\mathrm{mm}$ film. ${ }^{7}$ These files were stored as JPEG files at medium resolution. The 15 remaining images were digitized in black and white (grayscale) at the same resolution.

Each image in Caillebotte's collection was then matched to another image, selected with several constraints: The paired image must have been by the same artist, in the same general style, from roughly the same period (median difference $=2$ years, $S D=3.7$ years), and with the same type of subject matter. The idea is that these matched images are ones that Caillebotte might have collected had he had the opportunity, and in many cases he probably did. The 66 comparison images were selected from the same general sources as those for the Caillebotte images and were screened for reproduction quality in the same way. The right panels of Figures 1 and 2 show eight examples. Comparison images were chosen without regard for their location-currently in the Musée d'Orsay, another museum, or a private collection. These are listed in the right column of the Appendix. These images were digitized at the same resolution as their Caillebotte counterparts. If matched to a black-and-white image, they too were digitized in grayscale. In all, 33 of the comparison images were from Orsay, 27 from other museums, and 6 from private collections or in locations unknown. In addition, among the 66 pairs, there were 16 direct comparisons of images from the Orsay, 5 of images from other museums, and 1 of images in private collections.

When not referred to by title, the paintings will be discussed by image numbers, 1-66, with the additional notation of $c$ (for the Caillebotte images) and $n$ (for their matched pairs, the non-Caillebotte images). Thus, Image 26c is Monet's La Gare Saint-Lazare ("The SaintLazare train station," Figure 2A), and Image 8n is Degas' L'Absinthe ("The absinthe drinker," Figure 1F). Table 1 presents these image pair numbers and an abbreviated or descriptive form of their English titles for data presentation and discussion.

\section{Determination of Image Frequency}

After I selected the images, a research assistant and I became sufficiently familiar with all 132 to recognize them spontaneously. Carrying copies of the images for reference, we then began to consult all the relevant books we could find in the Cornell Fine Arts Library and, later, 12 other Cornell campus libraries. Our intent was to record every occurrence of each of the 132 images in Cornell's more than 6 million volumes. Carrying an electronic notebook with us, we created and then continually updated separate databases for each of the 132 images. These were Microsoft Excel files that registered each occurrence with its source's call number, author, title, date of publication, page number, and occasionally, other information. We found target images in books along shelves by call number according to (1) each of the eight artists, which included monographs, exhibition catalogs, catalogues raisonnés, and works in sections on painting, sculpture, pastels, drawings, watercolors, prints, and combined media; (2) all other artists closely or even loosely associated with Impressionism, including those generally painting earlier, such as Corot, Courbet, and Turner, those painting at the same time, such as Fantin-Latour and Forain, and those painting later, such as Gauguin, Seurat, Toulouse-Lautrec, and Van Gogh;(3) artistic terms, such as Impressionism, Neoimpressionism, and Postimpressionism, but also the Nabis, Naturalism, Japonisme, Cubism, Symbolism, and more generally, 19th century 

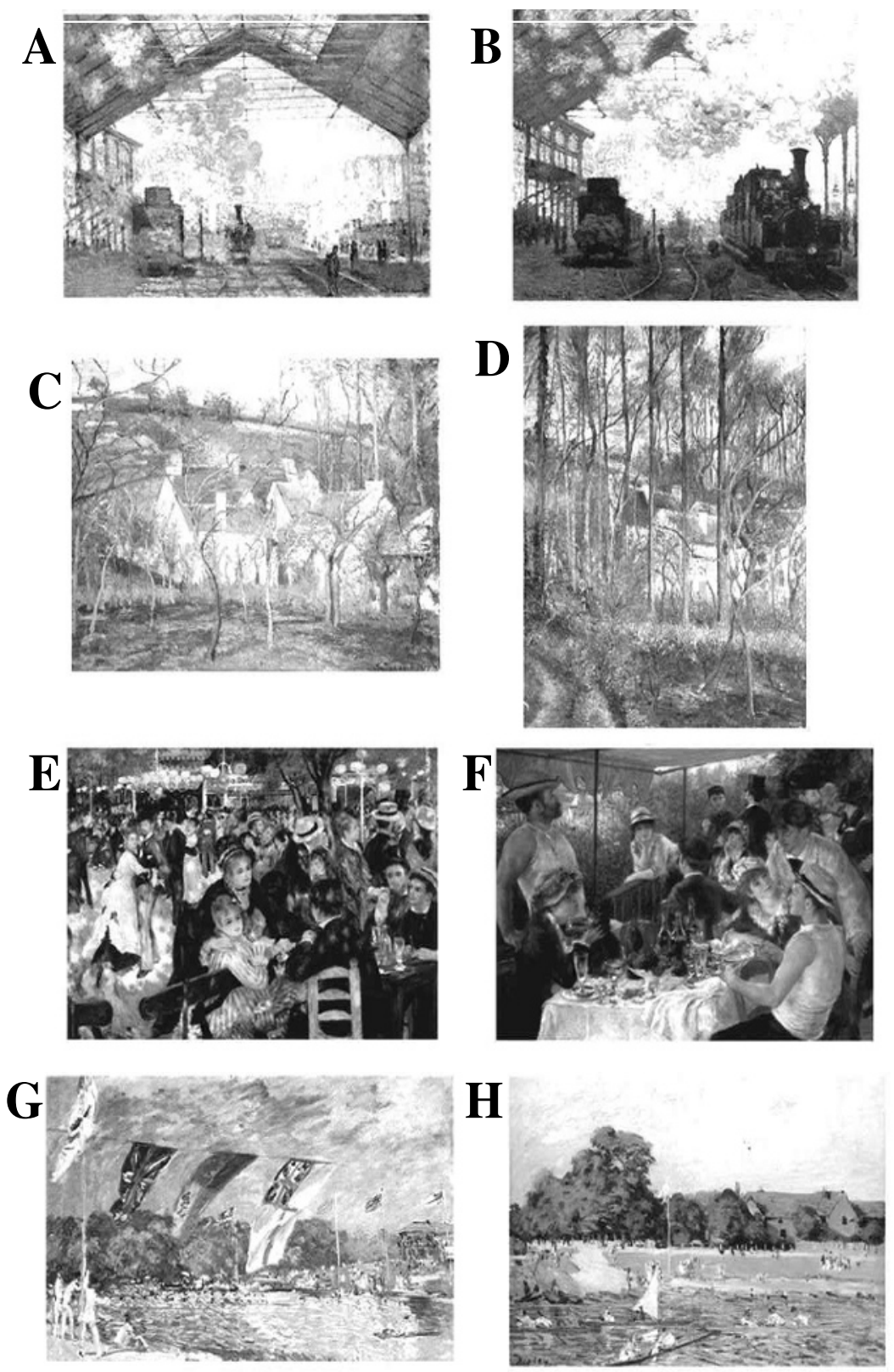

Figure 2. A second group of eight Impressionist images. Again Caillebotte owned the four on the left, and again, these 4 pairs were among the 66 pairs used in these studies. Panels $A$ and B are Claude Monet's La Gare Saint-Lazare ("The Saint-Lazare train station," Image 26c; Paris, Musée d'Orsay) and his La Gare Saint-Lazare, l'arrivée d'un train ("The arrival of a train at the Saint-Lazare train station," Image 26n; Cambridge, MA, Fogg Museum of Art); panels $\mathrm{C}$ and $\mathrm{D}$ are Camille Pissarro's Les Toits rouges, coin du village, effet d'hiver ("Red roofs," Image 43c; Paris, Musée d'Orsay) and his La Côte des Boeufs à Pontoise (Image 26n; London, National Gallery); panels E and F are Pierre-Auguste Renoir's Bal du Moulin de la Galette (Image 54c; Paris, Musée d'Orsay) and his Le Déjeuner des canotiers ("Luncheon at the boating party," Image 54n; Washington, DC, Phillips Collection); and panels $\mathrm{G}$ and $\mathrm{H}$ are Alfred Sisley's Les Régates à Molesey ("The regatta at Molesey," Image 59c; Paris, Musée d'Orsay) and his Les Régates à Hampton Court (Image 59n; Zurich, Stiftung Sammlung Emil G. Bührle). Again, see the Appendix for more information. Panels $A, C, E$, and $G$ are reprinted with permission of the Musée d'Orsay, Paris, France; panel B is reprinted with permission of the Harvard University Art Museums; panel D is reprinted with permission of the National Gallery, London; panel $F$ is reprinted with permission of the Phillips Collection, Washington, DC; and panel G is reprinted with permission of the Sammlung E. G. Bührle, Zurich, Switzerland. 


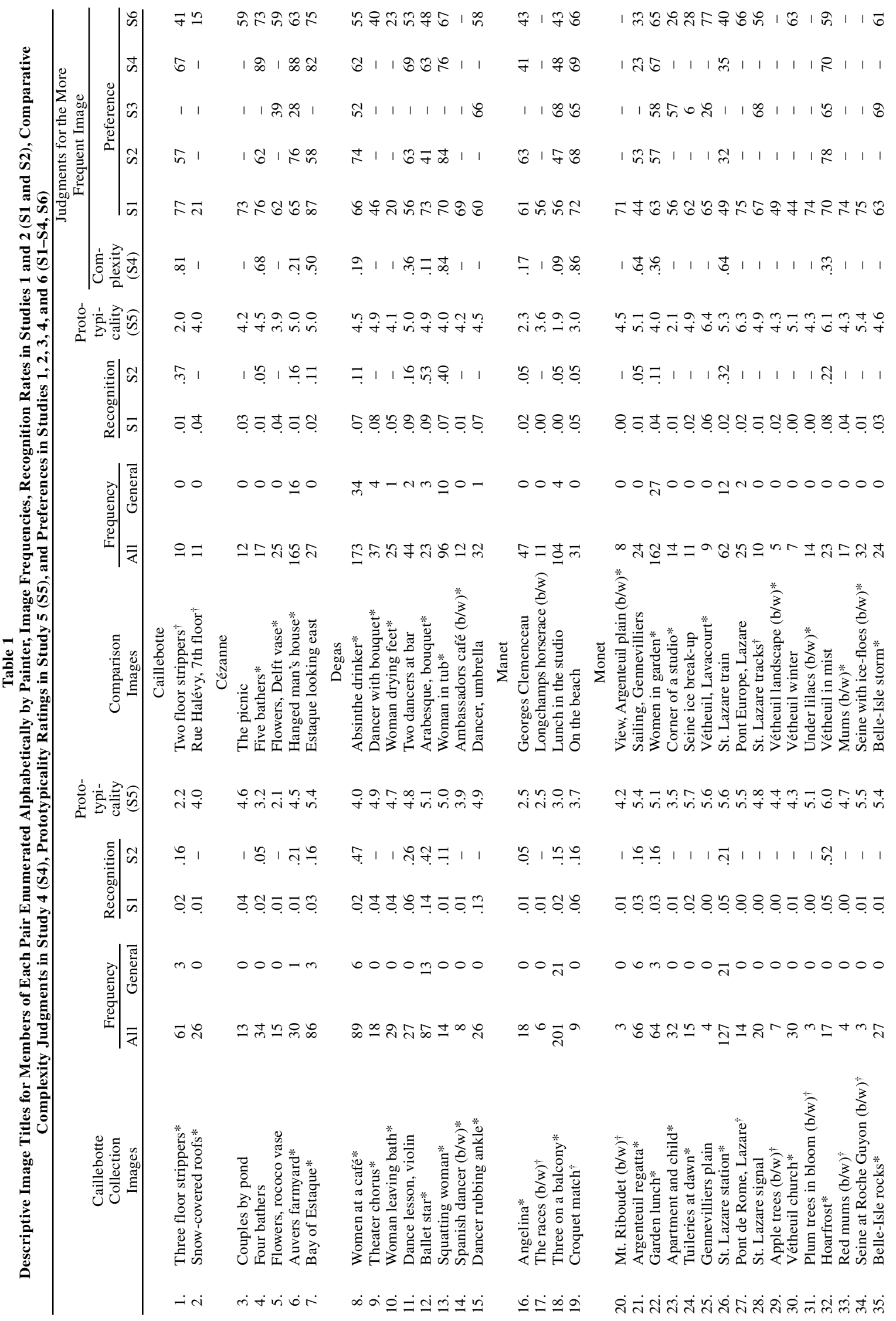




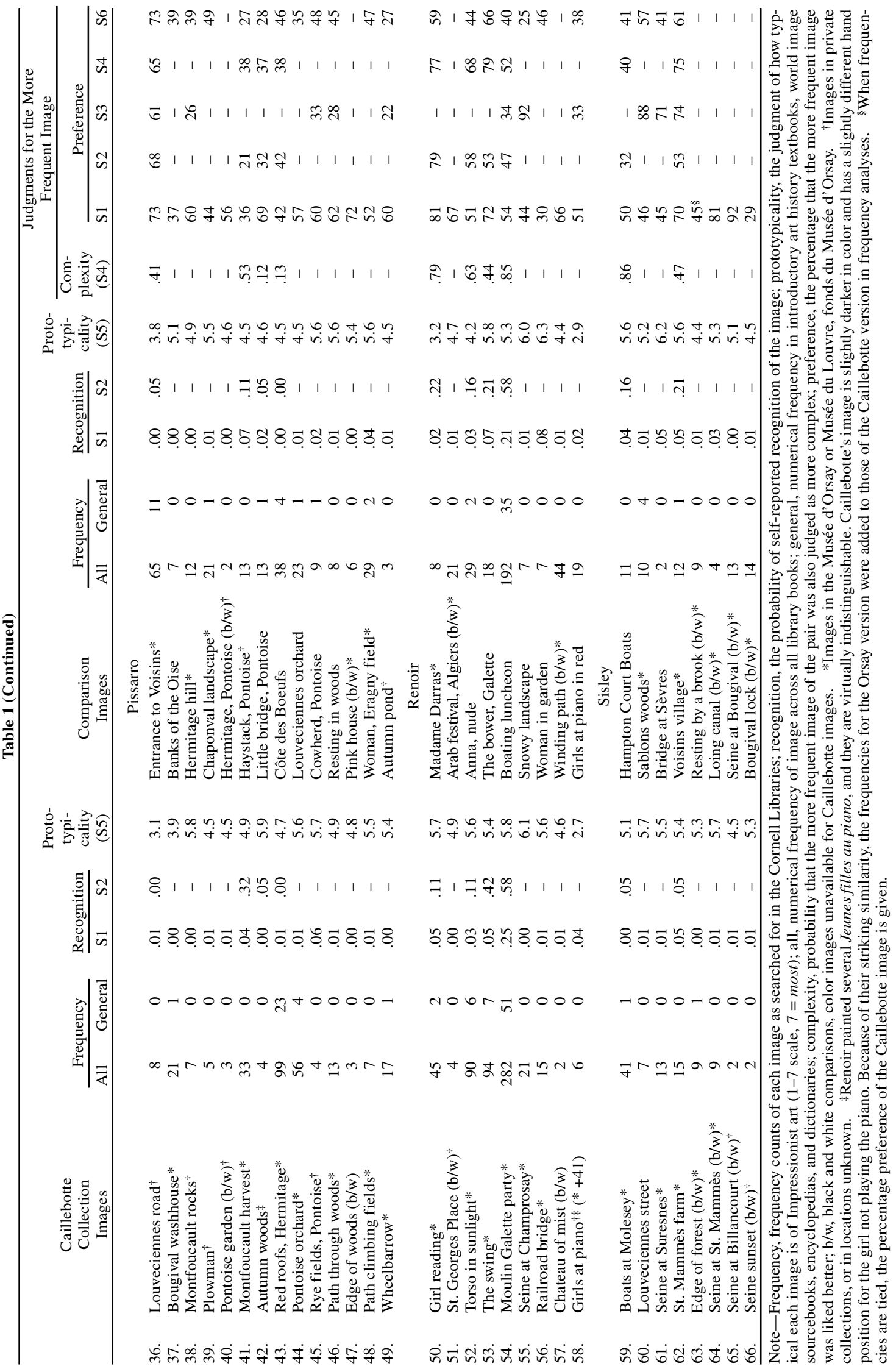


art, French art, European art, and modern art; (4) painting and drawing techniques and the use of color; (5) landscapes, seascapes, portraits, still lifes, and flowers; (6) feminism, nudes, bodies, fashion, visual culture, and modern life; (7) aesthetics and form; (8) art appreciation and the psychology and philosophy of art; (9) pictorial art as it relates to music, poetry, and the other arts; (10) guidebooks to Paris and the French patrimoine, a reflection of French culture, geography, and history; (11) books on art collectors and collecting; (12) books on museums and museum design; (13) source books of museum holdings around the world and their guide books; (14) books of images for sale as posters; (15) auction house catalogs; (16) introductory art history textbooks; (17) world art textbooks and sourcebooks; (18) encyclopedias and dictionaries specific to art; and (19) general encyclopedias.

Later, it will be useful to distinguish among image appearances in three types of books: (1) the most focused texts featuring one of the eight artists; (2-15) the broader, more topical texts featuring many artists or those featuring one artist but using works of another (e.g., a book on Cézanne with an image by Pissarro); and (16-19) general textbooks, sourcebooks, encyclopedias, and dictionaries, whose purpose it is to cover all of art across all of time. In this process, we attended to shelf lists and the on-line catalog, recalled books when necessary, obtained missing books on interlibrary loan, and perhaps most important—and certainly most delightful—simply roamed the aisles of the Cornell Fine Arts and other libraries in search of candidate volumes. We thumbed through as many as were deemed even remotely likely to have any of these images.

Several constraints governed our tallies, following the spirit of counting the different "acts of writing or curatorial practice" (Ferguson, 1999): Multiple copies of the same book were not considered (these were intended for the same audience, had the same call number, and were published at the same time), although a foreign language book and its English language translation were counted separately, as well as different editions of the same book (these were intended for different audiences, had different call numbers, and were published at different times). Occasionally, in a given book, there would be both a full image and a detail of it. Both of these were counted, with the idea being that if the author wished to show the image twice (or more), it was important to count it twice (or more). In the databases, we recorded the number of details for each image and the number of times the image appeared in color (vs. black and white), on covers, as frontispieces, or spread out on two pages versus one. None of these factors had any statistical leverage in the results that follow, so they will not be considered again.

We searched books-sometimes intensively, sometimes more leisurely-over the course of 20 months in at least 200 library visits. After several months, totals were accumulated each month or so and were compared, and correlations were computed. These were always extremely high $(r \mathrm{~s}>.99)$, and increasingly so as time pro- gressed. Thus, however many books we might have missed in assembling our databases, image counts that included them would not have changed the shape of the relationships among the frequencies reported here.

In all, we located 4,232 reproductions of the $132 \mathrm{im}$ ages in 980 different books. Multiple volume sets were counted as a single book. Publication dates were between 1901 and 2002. In this effort, possibly 6,000 books were examined. Frequencies of image occurrence ranged from 2 (1 Pissarro, 1 Renoir, and 3 Sisleys) to 282 (Renoir's Bal $d u$ Moulin de la Galette, Image $54 \mathrm{c}$ and Figure 2E). ${ }^{8}$ Mean frequency for all the images was 32.1; median frequency was 16. Distributions varied widely: Eight images occurred more than 100 times (including Figures 1D, 1F, $1 \mathrm{G}, 1 \mathrm{H}, 2 \mathrm{~A}, 2 \mathrm{E}$, and $2 \mathrm{~F}$ ), 13 from 50 to 100 times (including Figures 1A, 1E, 2B, and 2C), 27 from 25 to 49 times (including Figures 1C, 2D, and 2G), 44 from 10 to 24 times (including Figures $1 \mathrm{~B}$ and $2 \mathrm{H}$ ), and 40 fewer than 10 times. Thus, among the 132 images, there is a clear gradation from the high canon of Impressionism to its base corpus. Raw frequencies for the images in all the texts and in general texts are shown in Table 1, but a discussion of them will be interlaced with the results of Study 1.

An important question arises about the utility of these frequencies: How representative are the relative occurrences of these 132 images to what would be more broadly available in our culture? This is not an easy question to resolve. Nonetheless, one can approximate an answer in two ways. The first related question is: How representative are the numbers of books on each artist in the Cornell collections to all the books and other sources on these painters. This was assessed in three ways.

\section{On the Representativeness of the Cornell Collections}

First, in April 2001, the on-line catalog of the Cornell libraries was searched for all occurrences of the last names of eight artists, used as keywords. Individual records were inspected for relevancy, and the number was recorded. ${ }^{9}$ The same was then done on line for the Bibliography of the History of Art (BHA), a professional database of books and articles since 1973 that can be searched by the same keyword technique. The correlation between the frequencies of the relevant titles in the Cornell collections and those in the BHA was very high $(r=.97, p<.001)$. Relative counts are shown in Table 2 . This suggests that the holdings at Cornell on these artists and the scholarly work done on them in the last third of the 20 th century are quite tightly related. Given the assumption that the artworks of each artist should be distributed roughly in the same way in both corpora (Cornell's and the BHA's), Cornell's collection seems representative of the professional literature.

Second, an on-line search was conducted of current and out-of-print books on Amazon.com, screened in the same manner as before. The results are also shown in Table 2, and the correlation between the Cornell hold- 
Table 2

For Each Painter, the Number of Sources Found in Electronic Searches, the Number of Books in the Cornell University (CU) Libraries With Their Images, and the Indices of the Representativeness of their Images in the Entire Stimulus Set, Those in the Caillebotte Collection, and Those of the Images Matched to Them

\begin{tabular}{|c|c|c|c|c|c|c|c|c|c|c|}
\hline \multirow[b]{3}{*}{ Artist } & \multicolumn{6}{|c|}{ On-Line Searches } & \multirow{3}{*}{$\begin{array}{c}\text { Number } \\
\text { of Books } \\
\text { in CU } \\
\text { Libraries } \\
\text { With } \\
\text { These } \\
\text { Images }\end{array}$} & \multirow{2}{*}{\multicolumn{3}{|c|}{$\begin{array}{c}\text { Indices of } \\
\text { Obtained/Expected } \\
\text { Frequencies }\end{array}$}} \\
\hline & \multicolumn{3}{|c|}{$\begin{array}{c}\text { Academic and } \\
\text { Popular Sources }\end{array}$} & \multicolumn{3}{|c|}{ Google $(\times 1,000)$} & & & & \\
\hline & $\begin{array}{c}\mathrm{CU} \\
\text { Libraries }\end{array}$ & BHA* $^{*}$ & Amazon & Painter & $\begin{array}{l}\text { Painter } \\
\text { +"Art" }\end{array}$ & $\begin{array}{l}\text { +"Impres- } \\
\text { sionism" }\end{array}$ & & $\mathrm{All}^{\dagger}$ & $\begin{array}{l}\text { Caille- } \\
\text { botte }\end{array}$ & $\begin{array}{c}\text { Comparison } \\
\text { Images }\end{array}$ \\
\hline Caillebotte & 16 & 90 & 8 & 8.8 & 5.0 & 1.6 & 61 & - & - & - \\
\hline Cézanne & 243 & 1,200 & 83 & 116.0 & 47.2 & 8.7 & 230 & 0.69 & 0.39 & 0.53 \\
\hline Degas & 156 & 853 & 119 & 131.0 & 62.0 & 14.3 & 330 & 1.34 & 0.70 & 1.09 \\
\hline Manet & 168 & 942 & 84 & 155.0 & 48.2 & 9.3 & 240 & 0.93 & 0.68 & 0.52 \\
\hline Monet & 156 & 800 & 130 & 846.0 & 230.0 & 25.2 & 316 & 1.28 & 0.79 & 0.89 \\
\hline Pissarro & 60 & 414 & 27 & 41.6 & 20.3 & 5.8 & 221 & 1.46 & 0.95 & 0.92 \\
\hline Renoir & 115 & 372 & 73 & 298.0 & 105.0 & 13.0 & 420 & 2.04 & 1.46 & 1.11 \\
\hline Sisley & 33 & 77 & 8 & 153.0 & 14.2 & 3.5 & 70 & 0.56 & 0.38 & 0.32 \\
\hline
\end{tabular}

*BHA is the Bibliography of the History of Art. $\quad$ The obtained variable is the number of books in the Cornell libraries with any of the selected images by each painter (column 8 ). The expected variable is the number of books found in the on-line catalog, using the painter's name (column 2), plus the 91 books in the catalog on Impressionism, screened for content.

ings and the Amazon listings is reasonably high $(r=.80$, $p<.02)$. Differences are not many. The Amazon offerings overrepresented Monet and underrepresented Cézanne, as compared with the Cornell holdings and the BHA listings.

Third, Internet explorations were conducted in April 2002, with the search engine Google. Search was done three ways: first, using the last name of the painter only, then the name in conjunction with "art"; and then the name plus "Impressionism." The results are shown in Table 2. None of these was reliably correlated with the frequencies in the Cornell collections or in the BHA ( $r \mathrm{~s}<.36$, n.s.). Monet and Renoir were overrepresented, and Cézanne and Manet were underrepresented, as compared with the Cornell collections and the BHA.

\section{On the Representativeness of the Images}

The second methodological question concerns the relation of the stimuli used here to the Impressionist canon. To this end, an index of obtained versus expected $(O / E)$ values was created for the images of each painter. Its numerator for each artist is the total number of Cornell books in which any of his stimulus images appeared. This is the obtained value, $O$ (column 8 of Table 2 ). The denominator is the expected value, $E$. This is the total number of Cornell books accessed using the artist's name as a keyword and screened for content (column 2 of Table 2), plus the number of books accessed using the open-ended keyword "Impression\$." In the latter count, books on Postimpressionism were excluded, and the residual was checked for relevant content and for the presence of many images. ${ }^{10}$ These totaled 91 . The logic of the index is as follows: If the artist's works among these stimuli were central to his oeuvre, one might reasonably expect that at least one of them would appear in every book on the painter and in every book on Impressionism generally. In this manner, if the stimuli were representative, index values $(O / E)$ should be near 1.0.
The results are shown in the column 9 of Table 2. As one can see, Renoir's index (2.04) was more than twice what might be expected. This is in good measure due to his Bal du Moulin de la Galette, part of the Caillebotte legacy. His index would be nearer unity (1.43) without it. Three other indices were reasonably above 1.0: those for Pissarro (1.46), Degas (1.34), and Monet (1.28). Those of Manet and Cézanne were less, partly because the numbers of their paintings used here were fewer than those for the other artists. In addition, Manet's was less (0.93) also because of extensive literatures on his Déjeuner sur l'herbe (1863), his Olympia (1863; both in the Orsay), his Le Bar aux Folies-Bergère (1882; Courtauld Institute, London), and works on Spanish influences and topics in his art. Except for the Folies-Bergère, Caillebotte's collection of Manet's work, and images here matched to them, was subsequent to these. In a reverse manner, Cézanne's index (0.69) was considerably lower, because Caillebotte's collection was prior to many more important works, such as the near-Cubist series of $L a$ Montagne Sainte-Victoire. Indeed, these are subsequent to Caillebotte's death. Finally, Sisley's index was lower still $(0.56)$ for at least two reasons. First, his works are increasingly excluded from presentations of Impressionism, and second, his images from the more celebrated series on the floods at Marly (e.g., L'Inondation à PortMarly in the Orsay) were not included here. The fact that indices for these seven artists are generally greater than 1.0 (mean index $=1.19$ ), coupled with the high correlation of works in the Cornell collections with those in the BHA database, suggests that these stimuli form a suitable and representative sample of the Impressionist canon.

Table 2 also shows two related indices in the last two columns: that for the representativeness of the Caillebotte images for each painter to the Impressionist canon and that for those images matched to them. Across artists, the means of these indices were 0.77 for both the 
Caillebotte images and their comparisons, suggesting that the two groups are well matched in representing each artist's work.

\section{STUDY 1 \\ Frequency Counts, Recognition, and Preferences for Images From the Impressionist Canon and Corpus}

Using the frequency counts of the images as an estimate of the likelihood of prior exposure, I set out to determine whether there was a relationship between the counts and viewers' preferences for the images and between the counts and viewer recognition. Also of interest were the relative preferences for, and recognition of, the Caillebotte and Orsay images.

\section{Method}

All JPEG files were commercially made into $5 \times 5 \mathrm{~cm}$ slides. Two carousel trays were prepared, with members of each pair in corresponding slots-one image from the Caillebotte collection in one tray and one matched to it in the other. Their order in sequence was random, with several constraints: No images by the same artist could follow one another; black-and-white pairs could not follow each other; half of the Caillebotte images appeared on the left, and half appeared on the right; and 31 images from the Musée d'Orsay appeared on the left, and 41 on the right.

Stimulus pairs were presented for about $8 \mathrm{sec}$ each. They were projected onto a large screen by two projectors. The smaller dimension of each image (vertical if landscape, horizontal if portrait) projected a size of about $8^{\circ}$ from the middle of the auditorium. Viewers were 166 Cornell University undergraduates enrolled in a perception course. They were asked to look at each pair and judge which image they liked best. In addition, should they recognize any image, they were to mark which of the two, or both, they recognized of each pair. No record was kept of where the viewers sat. Previous research using a wide variety of stimuli seen from a wide variety of locations in such situations has shown no effect (Cutting, Wang, Flückiger, \& Baumberger, 1999; Gibson, 1947; Kozlowski \& Cutting, 1977).

The viewers also filled out a brief questionnaire, indicating how many times they had visited the Johnson Art Museum on the Cornell University campus each year (54\% said at least once a year), the number of times they had visited any other museum (52\% said at least once a year), the number of times they had ever visited the Musée d'Orsay ( $8 \%$ had visited at least once), and how many art history courses they had taken (only $16 \%$ had taken any). The students also reported spending a mean of 10.8 hours per week on the Internet $($ median $=10, S D=9.3$ ).

\section{Results and Discussion}

The results divide several ways. In increasing order of psychological interest, first the results pertinent to the Caillebotte collection and to that of the Musée d'Orsay and then those interrelating recognition, preference, and frequency will be considered.

Caillebotte and the Orsay. Across the database, images from the Caillebotte collection did not appear with any different frequency than their matched pairs. Means were $33.5\left(S E_{\mathrm{m}}=5.8\right)$ and $30.6\left(S E_{\mathrm{m}}=5.1\right.$, n.s. $)$, respectively. In addition, the Caillebotteimages were not claimed to be recognized with any reliably different frequency-
$2.5 \%$ versus $2.9 \%$ (n.s.), respectively. And finally, the viewers expressed no preference for the Caillebotte images, choosing them $47.5 \%$ of the time (vs. $52.5 \%$, n.s.). Thus, there is nothing unusual here about the paintings and pastels in the Caillebotte collection. He cannot be said to have had extraordinary taste in the selection of his images over and above the selection of other images by groups of other collectors-at least for these comparisons, as judged by a contemporary, relatively naive, but appreciative artistic audience.

Next, consider the Musée d'Orsay. Images in its collection appeared significantly more often than those elsewhere. Means were $43.1\left(S E_{\mathrm{m}}=6.0\right)$ versus 20.9 $\left(S E_{\mathrm{m}}=3.2, p<.0001\right)$, respectively. This difference occurred even when the comparison was restricted only to those images in all the other museums (43.1 vs. 27.5, $p<$ $.005)$. This is not a surprise, since the French government and the Réunion des Musées Nationaux of France have been thorough in promoting their art for a long time. However, the viewers did not claim to recognize the images in the Orsay more often than others-2.8\% versus $2.6 \%$ (n.s.), respectively. As might be expected, viewers did prefer them somewhat more often- $54 \%$ versus $46 \%[r=.32 ; t(38)=2.14, p<.04]$ —but when frequency differences were factored out, there was no effect of images being in the Orsay $(t<1, \mathrm{n}$.s.). Thus, what distinguishes this selection of the Orsay holdings is only that its images appear more often.

What about Varnedoe's (1987, p. 202) claim that the state of France got the "cream" of the Caillebotte collection? Of course, an empirical analysis of the kind here carries a different force than an academic or professional assessment. Yet one must be wary of how this retrospective prophecy may have been fulfilled; certain of Caillebotte's images went to the state of France, which made them available and promoted them, which we now revere. It is unequivocal that the Caillebotte images in the Orsay appear more often than those that are not (means of 49.7 vs. 9.6, $p$ <.0001). ${ }^{11}$ And indeed, the Caillebotte Orsay images were somewhat preferred over their matched pairs (53\% to $47 \%$, n.s.), whereas those not in the Orsay were not $(42 \%$ vs. $58 \%, p<.01)$. But once the difference in relative frequency is factored out $[r=.50 ; t(63)=$ $4.08, p<.0002]$, there was no residual effect of images being in the Orsay $(r=.24 ; t<1$, n.s.). Thus, being in the Orsay does not make a painting part of the canon independently of how often it appears. Instead, an image may appear more often because it hangs in the Orsay (and hung in its predecessor museums), and appearing there often goes some distance toward maintaining an artwork in the canon as acknowledged by professionals and the public.

Finally, paintings and pastels that reside in any museumthe Orsay or elsewhere-appeared reliably more often than those in private collections $(37.4 \%$ vs. $5.6 \% ; p<$ $.0001)$, they were recognized more often $(3.3 \%$ vs. $1.5 \%$; $p<.0001)$, and when paired directly they were preferred more often $(61 \%$ vs. $39 \% ; p<.001)$. None of this, of 
course, is a surprise. Essentially, by definition, artworks in private collections cannot be in a canon. What drives all of this, at least statistically, would appear to be frequency of appearance. The other relationships among frequency, recognition, and preference are the centerpiece of the findings in this study and are a bit complex.

Recognition and frequency. Viewers claimed to recognize only $2.7 \%$ of all the images, but this varied according to observer experience, as is shown in the top panel of Figure 3. Those having never taken an art history course, or having taken only one, recognized $1.6 \%$ of all images, and those having had at least two courses recognized $11.9 \%(p<.001)$. Those claiming not to go to an art museum each year recognized $1.1 \%$ of the images, whereas those claiming to go at least once a year recognized $4.1 \%(p<.001)$. Finally, those never having been to the Musée d'Orsay recognized $1.9 \%$, whereas those having been at least once recognized 13.4\% ( $p<$ $.001)$. Multiple regression showed that the number of images viewers claimed to recognize was correlated with how often they went to any museum $(r=.49, p<.0001)$ and how often they had been to the Musée d'Orsay $(r=$ $.49, p<.0001)$, but once these were factored out, not with how many art history courses they had taken $(r=$
.35 , n.s.). The first two factors accounted for $39 \%$ of the variance in recognition judgments across viewers $(R=$ $.62, p<.0001)$. Recognition of individual images ranged from $0 \%$ (2 Manets, 9 Monets, 10 Pissarros, 2 Renoirs, and 3 Sisleys) to 25.4\% (Renoir's Bal du Moulin de la Galette, Image 54c and Figure 2E). Rates for each of the 132 images are given in Table 1 . The general patterns will be discussed here.

Analyses were then conducted predicting viewers' recognition of all the images from three different sets of frequencies: (1) those from general texts, (2) those from more topical texts with narrower scope but not featuring a single artist, and (3) those from more focused texts and monographs featuring a single artist. The counts from the first group seem the most firmly in the Impressionist canon, those from topical books a bit less so, and those from more focused texts less firmly still, leaving those in none of the books except the catalogues raisonnés in the broad base of the corpus. Thus, in moving from high canon to corpus, it is best to compare the frequencies of images in (1) the most general texts with $(1+2)$ those in the general group plus the topical texts, with $(1+2+3)$ those in all texts. These can be conceived as different slices through likely cultural exposure.
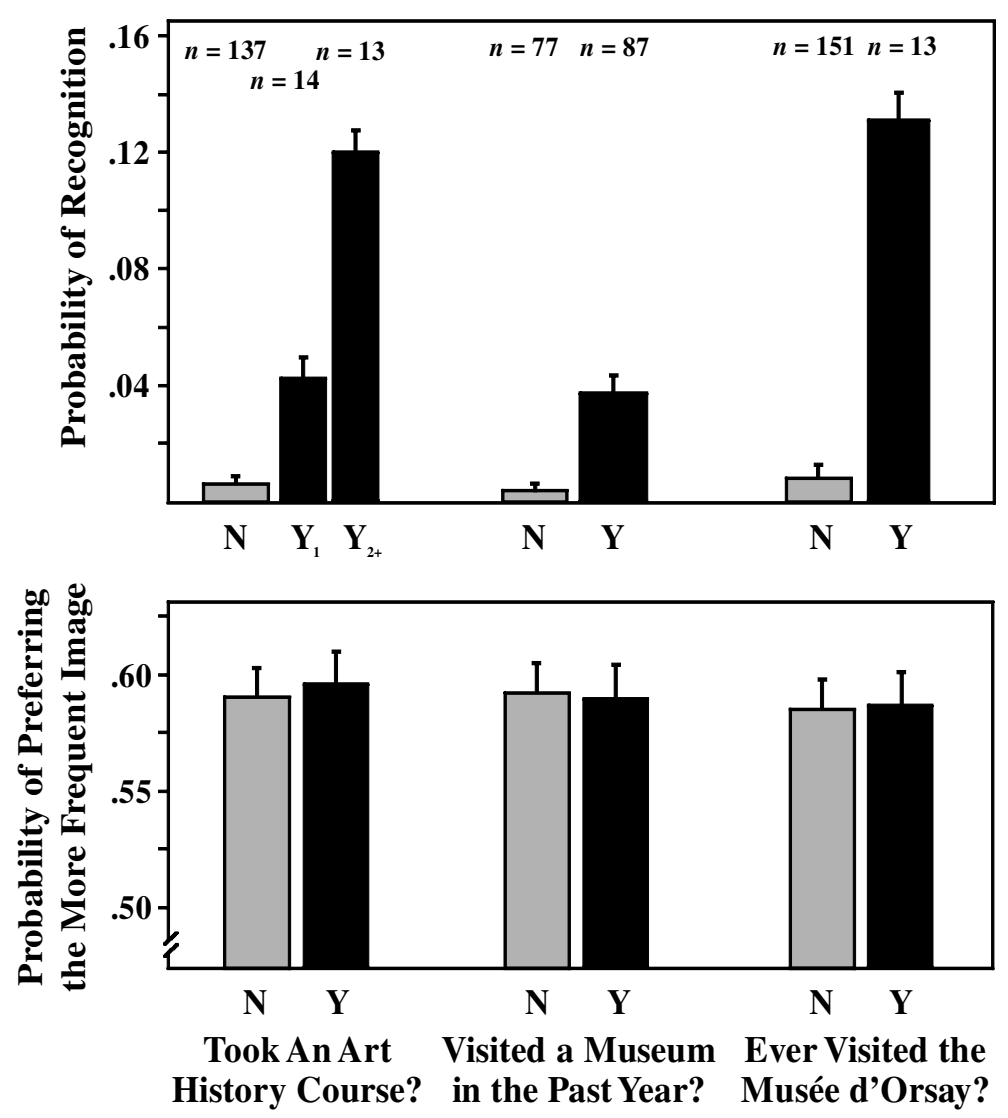

Figure 3. The contrasts between recognition and preference results as a function of observer sophistication and experience in Study 1. Standard errors are shown. 
Consider a hypothetical example: If an image appeared in five general texts, 15 topical texts, and 25 monographs, the numerical values for the three classes would be 5, 20, and 45. Psychophysical practice suggests that these should be logarithmically transformed. Since zeros occur (most images never appear in general texts) and since the $\log$ of zero is undefined, the natural $\log (n+1)$ was used, where $n$ is the value under consideration (Moreland \& Zajonc, 1977). Thus, the values above would be $\log (5+1), \log (20+1)$, and $\log (45+1)$, or $1.79,3.04$, and 3.83 , respectively. Since such measures are always correlated, multiple regression is the best statistical tool for titrating effects of the appearances of images in the different types of academic sources.

Claims of image recognition were most correlated with their $\log$ frequency of occurrence in general art texts $[r=.46 ; F(1,128)=7.5, p<.01]$, but not with the sum of the general and topical texts $[r=.41 ; F(1,128)<$ 1$, n.s. $]$ or with occurrences across all texts $[r=.43$; $F(1,128)=1.8$, n.s. $]$. The multiple correlation accounted for $23 \%$ of the variance in the data $[R=.48 ; F(3,128)=$ $12.0, p<.0001]$, but clearly, almost all of the effect came from the frequencies of images in the most general sources. This result is not a surprise. Those images should be the most recognizable. However, in this context, it is important to note that there is currently no introductory art history course at Cornell and that only 27 of $166(16 \%)$ undergraduates had taken any art history courses. Thus, I claim that recognition reflects general knowledge of particular viewers, not their perusal of introductory art history textbooks or encyclopedias in the Cornell libraries or elsewhere.

Most of the image pairs were in color, but 15 were black and white. Did this effect recognition? Yes. That is, when the differential frequencies were factored out, there remained an effect of color: Color images were claimed to be recognized $3.7 \%$ of the time, but blackand-white images only $0.7 \%[r=.31 ; F(1,127)=9.52$, $p<.003] .{ }^{12}$ The most frequently occurring black-andwhite stimulus was Image $57 \mathrm{n}$. If comparison color images are restricted to its value $(n=44)$ and less, the difference is still reliable $(2.8 \%$ vs. $0.7 \%, p<.01)$. Color also improves recognition of objects and scenes in laboratory studies (Joseph \& Proffitt, 1996; Oliva \& Schyns, 2000; Wurm, Legge, Isenberg, \& Luebker, 1993).

Note that no assumption is made that the observers' responses necessarily represent the true recognition of a particular painting or pastel. There is no way to verify them. Nonetheless, there are additional interesting trends. For example, against a backdrop recognition of $2.7 \%$, the 16 images by Degas were recognized at a rate of $6.1 \%$ $(p<.001)$, and the 7 of his images that were clearly dancers were recognized at a mean rate of $9.4 \%$. Recognition of the dancer images, it would seem, is an example of generic recognition-recognition by that individual only that he or she had seen images of Degas-like dancers before (for a laboratory analogue, see Monahan, Murphy, \& Zajonc, 2000). Given that there are 600 pastels and paintings of dancers in the Degas catalogue raisonné (Lemoisne, 1946), this is perhaps not entirely surprising.

Preference and frequency. Herein lie the key results of the study. Over all pairs, the viewers preferred the more frequently occurring image of each pair on $59 \%$ of all the trials. This highly reliable effect $[t(165)=9.09$, $p<.0001]$ is about the size of many mere exposure effects in the literature (e.g., Seamon \& Delgado, 1999). Indeed, 48 of the more frequent images in 64 pairs were preferred (with one tie in preference and one in frequency; $z=3.9, p<.001$ ). Unlike the recognition results, this effect was uniform across all types of observers, as is shown in the bottom panel of Figure 3. It occurred equally for those who never had had an art history course $[59 \% ; t(130)=8.14, p<.0001]$ and those who had taken at least one such course [59\%; $t(27)=4.01, p<.0001]$. It occurred for those not visiting a museum in the past year $[59 \% ; t(79)=5.1, p<.0001]$, those visiting once $[59 \% ; t(46)=6.8, p<.0001]$, and those visiting at least twice $[58 \% ; t(38)=5.4, p<.0001]$, and it occurred equally for those not visiting and those visiting the Musée d'Orsay (59\% each, $p$ s < .001). Importantly, when differences in recognition rates were compared with preferences for each of the 66 images pairs, there are no reliable correlation $(r=.18$, n.s.).

Bornstein (1989), among others, noted that although mere exposure effects are a function of number of exposures, the effect asymptotes with increasing numbers of presentations. Preferences were then compared against the difference in log values of the images for the three levels of texts in which they appeared. Again, if one image appeared in five encyclopedias, 15 topical texts, and 25 monographs, the natural $\log$ transformation of the frequencies of 6,21 , and 46 would be $1.79,3.04$, and 3.83 , respectively. If its comparison image appeared in 0 , 25 , and 40 such texts, the $\log$ of 1,26 , and 66 would be $0.0,3.25$, and 4.19. Differences in log values would then be $1.79,-0.21$, and -0.36 . These values would be used as inputs to the regression.

Multiple regression analysis showed that viewer preference was not correlated with the difference in log frequency of image appearance in the most general texts $(r=.36, F<1$, n.s.) or with the differences in the sum of frequencies in the first group and the topical texts $(r=$ $.37, F<1$, n.s.). However, it was reliably correlated with the difference in frequencies in all occurrences $[r=.54$; $F(1,62)=11.5, p<.001]$. The multiple correlation on preference results accounted for $30 \%$ of the variance in the data $[R=.55 ; F(3,62)=9.1, p<.001]$, again with most of the effect coming from a single source-this time, differences in overall frequency. Overall frequencies for each image, I claim, act as a proxy for the likelihood and frequency with which an individual may have been exposed to that image in his or her broader cultural experience. Interestingly, the correlation between preferences and the differences in occurrences in all books $(r=.54)$ is the same regardless of whether all the occurrences of the images since 1901 are considered, or only those since 1989. The latter, of course, are likely the oc- 
currences correlated with what is most relevant to these viewers. This result also speaks strongly to the stability of the canon of images across the course of the 20th century, a topic to which I will return in the conclusion.

A variety of other frequency transforms were correlated with preference results, but none provided as strong a correlation as $\log (n+1)$. Given this result, the greater the difference in the logarithms, the stronger the preference should be. Indeed, this is what occurred. Figure 4 shows the relative preferences for the more frequent image across three groups of image pairs. The increasing trend seen in the figure is what drives statistically reliability $[r=.54 ; t(64)=5.1, p<.0001]$.

Unlike recognition responses, preferences were not affected by color versus black-and-white presentation. That is, once the differences in relative frequencies of the various types of books are factored out, there is no remaining contribution of color $[F(1,61)<1$, n.s.]. Nonetheless, without considerations of frequency, the more frequent image in a black-and-white pair was actually preferred more often $(67 \%)$ than was the more frequent image of a color pair [57\%; $t(62)=2.37, p<.01]$. This would appear to be due to variance in small numbers: The generally lower frequencies of occurrence for blackand-white pairs generated greater mean difference ratios (4.9:1) than for color pairs (2.8:1).

In addition, all digital files were inspected for mean luminance and RGB values. Preference within pairs was not related to differences in luminance $(r=.11, p>.35)$ or to distributions of red $(r=-.04)$, green $(r=-.05)$, or blue $(r=.03)$ colors. Indeed, the multiple correlation of all these variables was also not significant $(R=.09, p>.20)$.

\section{STUDY 2}

\section{Preference and Recognition in an Older Group}

The goals of this second study were to replicate the primary results of Study 1 with an older group. In par-

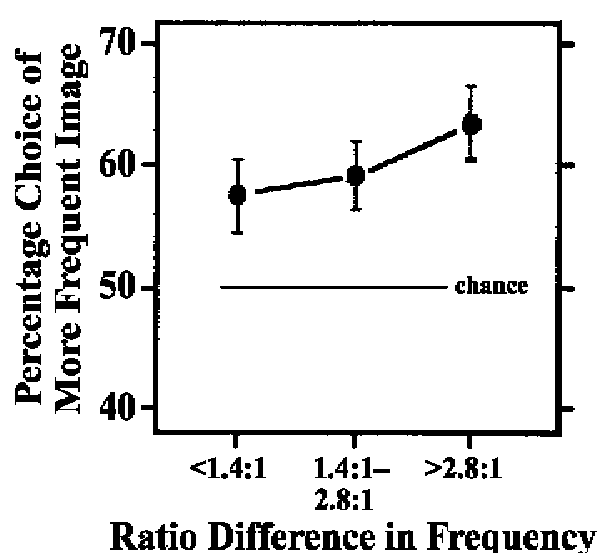

Figure 4. Difference in the ratio of overall frequency of the images in the pairs and the mean preference of the more frequent of the pair in Study 1. In general, images were preferred over their mates as a function of how much more often they occurred. ticular, the first study showed preferences related to differences in frequencies of occurrence for pairs of images and no relation between preference and recognition. This joint result is important for demonstrating mere exposure. Nonetheless, the lack of relation could be due, in part, to a floor effect, because so few of the images were claimed to be recognized. An older group would likely recognize more.

\section{Method}

Twenty-five pairs of images were selected from the 66 pairs used in Study 1. These are indicated in Table 1-1 Caillebotte, 3 Cézannes, 4 Degas, 3 Manets, 4 Monets, 4 Pissarros, 4 Renoirs, and 2 Sisleys. These were among the more frequent in the database of images from all books (mean frequency of 61.0 vs. overall mean of 32.1 in Study 1). They were also among the more recognized (mean of $4.8 \%$ vs. $2.7 \%$ in Study 1). No black-and-white pairs were used in this study. To vary presentation format, digital images were mounted in pairs on the same slide as part of a PowerPoint presentation. The left-right arrangement of half the pairs was reversed from that of Study 1, and the presentation order was also changed, but otherwise with the same constraints. In all, 13 Caillebotte images appeared in the left, 12 on the right; 14 Orsay images were on the left, 16 on the right. For most of the viewers, the largest dimension of each image subtended about $8^{\circ}$. As a group, 9 faculty members (mean age $=46$ years) and 10 graduate students (mean age $=$ 25 years) viewed the 25-pair sequence; 12 had visited the Musée d'Orsay at least once. Each made preference judgments and marked which images they remembered having seen before.

\section{Results and Discussion}

This group reported recognizing $18.6 \%$ of the images, many more than in Study $1[t(47)=7.8, p<.0001]$. Individual image rates are given in Table 1. Claims of recognition were unrelated to frequencies of appearance in all books $(t<1$, n.s. $)$ and in general tests $[t(47)=1.2$, n.s. $]$ and were unrelated to their preferences $[r=-.31 ; t(23)=1.6$, n.s.]. There was no difference in recognition of Caillebotte versus comparison images and, independent of frequency, no superior recognition of Orsay images ( $t \mathrm{~s}<1$, n.s.).

Nonetheless, as in Study 1, the viewers preferred the more frequent image of each pair-here, $57 \%$ of the time $[t(23)=3.6, p<.002] ; 17$ of 25 pairs showed this effect $(z=2.2, p<.02)$. Rates for each comparison are given in Table 1. This set of images had about the same preference margin in Study 1 (58\% vs. 42\%). In addition, there was a high correlation of preferences among the 25 image pairs used in the two studies $(r=.84, p<.0001)$. Again, preferences were related to the log difference in frequencies across all books $[r=.57 ; F(1,22)=4.7, p<$ $.05]$, but less so to the log difference in frequencies in general texts $(r=.43, F<1)$. Independent of frequency, however, there was no preference for Caillebotte images or Orsay images $(t \mathrm{~s}<1$, n.s.). Thus, the major features of the results of Study 1 were replicated.

\section{STUDY 3 \\ Preferences of Children}

The goal of this study was to determine whether the pattern of preference results found in Studies 1 and 2 
might be found in a group of children. Should children's preferences match those of previous studies, something other than mere exposure must be at work; children simply lack broad exposure to art. Here, I also wanted to focus on a group of images that would be least likely to have been seen before.

\section{Method}

Twenty-four different pairs of images were selected from the 66 pairs. These are indicated in Table 1: 2 Cézannes, 2 Degas, 2 Manets, 7 Monets, 5 Pissarros, 3 Renoirs, and 3 Sisleys. Nineteen pairs contained images that were among the least frequent from all the books-mean image frequency of 15.0 versus 32.1 in Study 1 . These will be called rare images. For comparison purposes, five pairs containing the most frequent images were also includedImage Pairs 6, 8, 18, 22, and 54, with a mean frequency of 146 per image. These will be called common images. Mean Study 1 preference rates for the more frequent images were $59 \%$ for both the rare and the common pairs. Nine of the 24 pairs had been used in Study 2; 5 were common-image pairs. Again, no black-and-white pairs were used in this study. Again, digital images were mounted in pairs on the same slide as part of a PowerPoint presentation. The left-right arrangement was balanced and randomized for the Caillebotte images and for the more frequent images, and the presentation order was randomized anew. Otherwise, the same constraints were followed as those in Study 1.

Sixty-three students in a Montessori school participated in three groups as part of an art class. There were 13, 28, 19, and 10 students, whose ages were $6,7,8$, and 9 years old, respectively. In addition 5 teachers participated. Each made preference judgments on an answer sheet. Particular care was taken that all the students understood the instructions. Pairs were presented for a minimum of $10 \mathrm{sec}$ each. Questions were allowed during the tests, so presentation rates varied.

\section{Results and Discussion}

These children showed no preference for the Caillebotte $(49.5 \%$ vs. $50.5 \%)$ or Orsay $(45.2 \%$ vs. $54.8 \%$; $t$ s < 1, n.s.) images. More important, they also showed no preference for the more frequent image of each pair$51.2 \%$ versus $48.8 \%[t(22)=.26, p>.75]$. Common $(49.4 \%$ vs. $51.6 \%)$ and rare (52.0\% vs. $48.0 \%)$ pairs did not differ in this regard. Interestingly, mean teacher preference was $60 \%$ for the more frequent image of each pair $[t(22)=4.1, p<.06]$. The children's responses, however, were far from random; they seemed to like paintings with brighter colors. Responses of each age group correlated reliably with those of all other age groups $[r s>.63 ; t \mathrm{~s}(22)>$ $3.9, p \mathrm{~s}<.001]$, but they did not correlate with the preferences of the adults of Study 1 for the same images ( $r=$ $-.16, p>.40)$. Overall preferences for more frequent images were $48.7 \%, 47.1 \%, 53.0 \%$, and $55.8 \%$, respectively, for the 6-, 7-, 8-, and 9-year-old groups. Nonetheless, the variance was large, and the apparent increasing trend was not reliable, either for all the pairs $[t(61)=$ $1.56, p>.12]$ or for the rare pairs $[t(61)=1.6, p>.10]$.

Thus, whatever governed the adult preferences in Studies 1 and 2 is not operative in the preferences of children. This is an important null result. Although elementary school children may have seen a few Impressionist paintings before, they lack the broad cultural exposure to Impressionist art that adults have experienced.

\section{STUDY 4 \\ Complexity Is Not a Mediator of Preference}

The goals of this fourth study were twofold: to replicate the preference results of Studies 1 and 2 and to explore the possible contributions of what is called stimulus complexity. Bornstein (1989) reviewed the literature on the relation between complexity and preference in laboratory experiments on mere exposure. He found that six of nine published studies found stronger mere exposure effects for complex stimuli than for simple stimuli, but more relevant are those using art works as stimuli. Here, the results are mixed. As was mentioned earlier, Berlyne (1970) and Zajonc et al. (1972) found opposing effects: one favoring a preference for complex stimuli, the other for those simpler. Nonetheless, the results of neither of these studies are generally applicable to representational art. Both confined themselves to abstract art (where bits and pieces could be counted in the context of complexity), and the latter carved up the artworks (under the assumption that a detail is less complex than the whole). Since complexity cannot be defined with rigor in many domains (Goodman, 1972), I let the observers define it for themselves.

\section{Method}

The viewers were 112 students from a classroom population, different from those in Study 1, but taking the same class a year later. Only $17 \%$ had taken an art history course, and $7 \%$ had been to the Musée d'Orsay. The same 25 pairs were used as those in Study 2, again in a PowerPoint presentation, but shown in a different order and with some counterbalanced changes in left-right positions. Again, pairs were presented for about $8 \mathrm{sec}$ each. Viewers were asked to make a judgment about which image in each pair they preferred. In addition, after the first run through of the stimulus set, the pairs were presented a second time, and the viewers were asked to make judgments about which image was more complex.

\section{Results and Discussion}

Again, from the database tallies of all the books, the more frequent image of each pair was preferred over its counterpart [ $58 \%$ vs. $42 \% ; t(24)=16.7, p<.0001]$, the same preference margin for these images as in Study 2. Again, 17/25 pairs followed this pattern $(z=2.2, p<$ $.02)$, but 4 pairs changed polarity of preference. Overall, preferences here were well correlated with those for the same images in Study $1(r=.80, p<.0001)$. Individual pair results are again shown in Table 1 . The correlation of preference with frequency differences across all the books was reliable and about the same as that in Study 1 $[r=.47 ; F(1,22)=6.3, p<.02]$, and again, that for general texts was not $[r=.21 ; F(1,22)=1.0$, n.s. $]$. Finally, the Caillebotte images were not preferred over their matched pairs ( $48 \%$ vs. $52 \%$, n.s.), Orsay images were not preferred either (49\% vs. $51 \%$, n.s.), and preferences were unrelated to museum trips or art history courses taken.

Complexity judgments were not correlated with preferences $(r=.18 ; t<1$, n.s.). Individual means for each image are shown in Table 1. Inspecting the relative judg- 
ments for each pair suggests that viewers were simply counting things, usually people, in the pictures. Consider four image pairs exhibiting strongly judged complexity differences. Degas's Femmes à la terrase d'un café, le soir ("Women outside a café in the evening") was judged as more complex than his L'Absinthe $81 \%$ of the time (Image Pair 8, Figures 1E and 1F). This may be because there are five people in the foreground of the former (with many in the background) and only two in the latter. Renoir's Bal du Moulin de la Galette was judged more complex than his Le Déjeuner des canotiers ("Luncheon of the boating party;" Image Pair 54, Figures 2E and $2 \mathrm{~F}$ ) by $85 \%$ of the viewers. This is likely because the former has uncountably many people and the latter but a dozen. Pissarro's La Côte des Boeufs à Pontoise was judged as more complex than his Les Toits rouges ("The red roofs") $87 \%$ of the time (Image Pair 43, Figures 1D and 1C). Both are views of the Hermitage in Pontoise in winter, but the former has more trunks of tall trees in the foreground. Finally, Manet's Le Déjeuner à l'atelier ("Lunch in the studio;" with three people) was judged more complex than his Le Balcon (with three people clearly visible and a fourth in shadow; Image Pair 18, Figures $1 \mathrm{H}$ and $1 \mathrm{G}) 91 \%$ of the time. This is probably because the table in the former is cluttered with food, and the scene is cluttered with other objects. There is no such clutter in the latter.

\section{STUDY 5 \\ Prototypicality is Not a Mediator of Preference}

Another account for the preference results of the Studies 1, 2, and 4 might be that viewers, when faced with making preference judgments, were comparing images on the basis of what they thought were the most representative (prototypical) Impressionist paintings. This study was designed to address this issue.

\section{Method \\ Twenty-one undergraduate students in an advanced visual percep- tion seminar viewed a PowerPoint sequence of 138 images-all 132 used in Study 1, plus 6 more by Gustave Caillebotte. ${ }^{13}$ These images were presented singly, and viewers rated them on a scale of 1 to 7 as to how representative each was of Impressionist paintings, with 7 being the most prototypical. Presentation was haphazard, with the constraints that images by the same artist could not follow one an- other, nor could black-and-white images. Six students had participated in either Study 1 or 4 , and 6 had taken at least one art history course.}

\section{Results and Discussion}

Prototypicality judgments were not correlated with the experimental variables of previous interest - the frequencies of the images in all the texts or in the introductory texts $(r \mathrm{~s}=-.05$ and .06 , respectively, n.s.) or the recognition rates in Studies 1 and $2(r s<.20$, n.s.). The differences in prototypicality judgments within a pair were also not correlated with preferences in Studies 1, 2, or $3(r s<.14$, n.s.) or complexity judgments in Study 4 $(r=-.05$, n.s.). Prototypicality judgments for individual images are shown in Table 1 . These null results may seem odd. After all, the most frequently occurring images are the prototypes of the canon. Nonetheless, it seems that the viewers were making judgments in a different way.

There were some striking effects of prototypicality judgments by painter. Most prototypic were the $16 \mathrm{im}$ ages of Sisley (mean rating $=5.28$ ). This is interesting, because he is clearly the least major of the seven "major" Impressionists, as suggested by the book counts in Table 2. Clustered next and together were the 32 works of Monet (4.96), the 28 of Pissarro (4.93), and the 18 of Renoir (4.96), with the first two reliably different from Sisley $(p s<.05)$. Clustered next, and reliably below these four, were the 16 works of Degas (4.59) and the 10 of Cézanne (4.24). Finally, well below these were the 8 of Manet (2.81) and the 10 of Caillebotte (2.77). Interestingly, Cézanne and Manet are often described as not really being Impressionist painters (Cézanne's most important works are later than the period of the 1870s and 1880s, and Manet's earlier), and Caillebotte as well. In addition, Degas never painted outdoors, which may have influenced judgments.

Other classifications of images also show some interesting differences. Of this set of 138 images, 90 can be classified as landscapes, 44 as portraits (often of groups and often outside), and 4 as still lifes. Mean ratings for landscapes (4.96) were reliably higher than those for portraits $[4.14 ; t(132)=4.71, p<.0001]$ and still lifes $[3.75 ; t(92)=5.2, p<.0001]$. Portraits and still lifes did not differ. It should be noted that, among these images and throughout their oeuvres, Sisley painted only landscapes, Pissarro mostly landscapes, Renoir mostly portraits, and Degas almost exclusively portraits.

\section{OVERVIEW}

\section{Preference}

The adult viewers of Studies 1, 2, and 4 generally liked the more frequent images of each pair, but the children of Study 3 did not. The effect in the adults was salient for differences measured across all the books in the Cornell databases; preference was not independently related to frequency differences in general texts. Preference strength was not a function of whether or not images were in color (Study 1; in Studies 2 and 4, all were in color), nor were they a function of whether or not the observers took trips to museums or attended art history courses.

\section{Recognition}

In Study 1, viewers recognized few of these Impressionist images-less than 3\%. Low recognition rates are requisite for laboratory demonstrations of mere exposure (Kunst-Wilson \& Zajonc, 1980). In that study, recognition rates were related to their frequency in general texts in the Cornell collections, but not to their frequency in all the books. Recognition was more frequent for color images, and it was also related to viewers' visits to the Musée d'Orsay and other art museums. In Study 2, a 
more seasoned set of viewers recognized $18 \%$ of a smaller set of images, but their recognition rates were not related to any frequency counts. In Studies 1 and 2, the viewers' recognition rates and preferences were not related, another requisite for laboratory demonstrations of mere exposure. This pattern has been recognized for quite some time (Zajonc, 1980), and there is neurophysiological evidence in its support (Elliott \& Dolan, 1998).

\section{Art Collections}

Several conclusions can be drawn. First, at least with respect to this type of analysis and experiment, images from the Caillebotte collection were neither preferred more often nor recognized more often than those matched to them, and the Caillebotte images were not more frequently occurring. Second and in contrast, the Musée d'Orsay holdings did occur more often in this sample. This is not a surprise. A systematic culling of images from the Orsay, which owns one tenth of all Impressionist paintings publicly available, would form the bulk of the core of the canon. ${ }^{14}$ However, with the same caveats as above, the Orsay's holdings were neither preferred nor recognized more often than other images matched to their frequencies of occurrence. Third, art in private collections is not in the Impressionist canon. These images occurred less often in the literature; they were less frequently recognized; and, lacking exposure, they were preferred less.

\section{On the Availability of Art}

Together, all of these trends support the idea that it is not where an image is, or who bought it, but how often it appears that affects public appreciation. Any artwork in a prized location — such as in the Musée d'Orsay—has a great advantage over other artworks, but systematic promotion by other museums and authors can overcome this advantage.

\section{Preference Judgments and Artistic Quality}

Surely the most interesting result of these studies is the relation of viewer preferences to how often images occurred in the Cornell libraries. Mere exposure aside, how else might this effect be accounted for? In discussing these results with colleagues, quite a few have suggested that perhaps viewers can simply judge quality, choosing the "better" picture. I don't believe this for a moment, but this is not the place to deal at length with this important and thorny issue. Here, let me simply acknowledge that there are many statements outside the art historical literature (e.g., Kant, 1794/1952; Pirsig, 1974) about people's culturally independent ability to judge quality, as well as many within it (e.g., Rosenberg, 1967; Woodford, 1983). Nevertheless, there are also more recent and culturally sophisticated counters to this claim (e.g., Bal \& Bryson, 1991; Cheetham, 2002; Moxey, 1994). Indeed, even Kenneth Clark, director of the National Gallery London in his 20s and, years later, a BBC icon of the visual arts, wrote in his memoirs (Clark, 1974):

At the age of nine or ten I said with perfect confidence "this is a good picture, that is a bad one"... This almost insane self-confidence lasted till a few years ago, and the odd thing is how many people have accepted my judgements. My whole life might be described as a long, harmless confidence trick. (p. 47)

Nonetheless, rather than trying here to rule out quality as a mediator of these results, let me try one last time to rule in mere exposure in a different way. This also provides an experimental effect that the notion of quality cannot explain.

\section{STUDY 6 \\ Preferences From the Combination of Cultural and Classroom Exposure}

If mere exposure mediates preferences for artworks, it ought to be possible to combine the effects of exposures to art across two situations - the viewers' personal histories with these images outside the classroom and classroom exposure to them.

\section{Method}

All 51 color pairs from Study 1 were used as stimuli. During 21 class periods in an introductory perception course (a year after Study 4 and 2 years after Study 1) and at the beginning of each lecture, students were presented 12 (on 18 days) or 13 (on 3 days) images, for a total of 255 presentations, 5 per pair. Across the 21 sessions and for each pair, the less frequent image from the Cornell Library tallies (see Table 1) was presented four times; the more frequent image was presented only once. Each image was presented singly for about $2 \mathrm{sec}$ as a PowerPoint slide, without comment. Previously, Harrison and Zajonc (1970), Marcus and Hakmiller (1975), and Vanbeseleare (1983) found no effects of presentation rates in the range from 2 to $50 \mathrm{sec}$; it is the presentation that matters, not its duration. Several constraints governed the composition of a day's set of slides: Images that would later be a test pair were not both presented, and no more than two images by the same artist could appear successively. More important, the same image did not appear twice on the same day or even on successive days.

On a 22nd class period, the 51 pairs of images were presented side by side in a PowerPoint presentation for about $6 \mathrm{sec}$ per pair in a new random sequence. Insofar as possible, three presentation factors were counterbalanced, left and right-more frequent images (25 left, 26 right), Caillebotte images (26/25), and Orsay images (28/30). In addition, no pairs of images by the same painter followed one another. The delays between exposure(s) and test ranged between 12 and 84 days. Although no studies in Bornstein's (1989) meta-analysis used delays as long as these, the general result across the literature is that short delays produce weak effects, those up to two weeks relatively strong effects, and naturalistic studies (such as those presented here) with indeterminate delays often produce the strongest effects. Indeed, Harrison (1977) showed that both heterogeneous display sequences (no successively repeating items) and longer delays enhance exposure-affect relationships.

The 116 viewers in attendance were asked to indicate on a response sheet which image of each pair they liked best. They also filled out a brief questionnaire, as in Study 1. Mean self-reported attendance over the 21 exposure sessions was 18 days (median = $19, S D=3.2$ ); $70 \%$ said that they visited the Johnson Art Museum 
on the Cornell University campus at least once a year, $47 \%$ said they visited at least one other art museum each year, 14\% said they had visited the Musée d'Orsay, and 22\% said they had taken at least one art history course. The students also reported spending a mean of $12.5 \mathrm{~h}$ per week on the Internet (median $=10, S D=9.6$ ).

For the critical comparisons, the preferences of viewers in this study were compared with those of Study 1, a similar group but without the systematic classroom exposure. Thus, major analyses here are based on a between-group design, looking at differences in preferences across the 51 image pairs.

\section{Results and Discussion}

More frequently published images were no longer preferred, accruing only $48 \%$ of all the judgments. This was reliably lower than the $57 \%$ preference in Study 1 for these 51 colored-image pairs $[F(1,50)=26.8, p<.001]$. Indeed, in 41 of 50 image pairs (with one tie), the more frequent image received a smaller proportion of preference judgments $(z=4.2, p<.0001)$. Preference rates for the more frequent image are found in the last column of Table 1. No other results proved statistically reliable: Image pairs that were published more frequently (sum $>$ $50, n=26$ ) changed, on average, as much as those that occurred less often (sum $<51, n=25 ; 9.0 \%$ vs. $9.2 \%$, respectively), and image pairs whose frequency ratios were relatively large $(>2.5, n=26)$ changed as much as those whose ratios were nearer unity $(<2.5, n=25 ; 10.1 \%$ vs. $8.1 \%$, respectively).

If observers were able to judge quality alone in the image pairs, their judgments should not have been contaminated by appearance differences in the classroom. To be sure, quality could still play a role, but such an account must then rely on two processes-mere exposure and quality assessment (however that might be done). My proposal is that these are one-process results and done on the basis of mere exposure inside and outside the classroom.

\section{CONCLUSION: MERE EXPOSURE IS A MEDIATOR OF CANON MAINTENANCE}

How might mere exposure affect an artistic canon, its reception, and its maintenance? All of us, as members of a culture, absorb what is around us. As visual beings, we digest images voraciously, even without noticing. A very small proportion of these images are from the Impressionist corpus and canon. Nonetheless, we respond to their occurrences in our future interactions with Impressionism. We like the ones we have seen before and, particularly, those we may have seen many times. ${ }^{15}$

We find these images everywhere. Impressionist paintings are not only in galleries, but also in books and on textbook covers, calendars, posters, coasters, tee shirts, and towels, and one can find them readily on the Internet. Mere exposure dictates that every occurrence can matter, particularly when an image is otherwise rare. Museum curators ought to note the full implications of this finding. Museums already do a reasonably good job at promoting their collections, but placing images everywhere and without cost to the public will go a long way toward ratifying the importance of their collections as received by the broader public. But the competition is stiff; everyone seems to be doing it. Currently, the correlation of what's in the literature and what's on the Internet, as shown in Table 2, is not high. If this difference is maintained, the canons of the future may change in directions independent of goals and interests of art professionals.

Thus, I claim that artistic canons are promoted and maintained, in part, by a diffuse but continual broadcast of their images to the public by museums, authors, and publishers. The repeated presentation of images to an audience without its necessarily focused awareness or remembrance makes mere exposure a prime vehicle for canon maintenance. Tacitly and incrementally over time, this broadcast teaches the public to like the images, to prefer them, eventually to recognize them as part of the canon, and to want to see them again. In turn, it seems likely that this implicit education also reinforces the choices made by professionals in what they present to that public. The public's appreciation rewards museums, scholars, and the publishing industry by demonstrating an interested and responsive audience.

And so it goes, with mere exposure cyclically reinforcing the canons through generations of authors and curators, on the one hand, and of museumgoers and book buyers, on the other. Although it may be tacit, I do not claim that this is necessarily a subversive trend or one to be denigrated. I claim it is part of the same force that binds a culture. It is part of our human nature, built on an evolutionary substrate that makes very good sense. It helps ensure steadiness in culture more generally and relative constancy in artistic canons more particularly.

\section{REFERENCES}

BAL, M., \& Bryson, N. (1991). Semiotics and art history. Art Bulletin, 73, 174-208.

BAZIN, G. (1958). Impressionist paintings in the Louvre (S. CunliffeOwen, Trans.). London: Thames \& Hudson.

Bérhaut, M. (1994). Gustave Caillebotte: Catalogue raisonné des peintures et pastels. Paris: La Bibliothèque des Arts.

Berlyne, D. E. (1970). Novelty, complexity, and hedonic value. Perception \& Psychophysics, 8, 279-286.

BERNAC, J. (1966). The Caillebotte bequest to the Luxembourg. Reprinted and translated in D. Sutton, Gustave Caillebotte, 1848-1894: A loan exhibition in aid of the Hertford British Hospital in Paris, 15th June-16th July, 1966. London: Wildenstein. (Original published in 1895)

Bonnano, G. A., \& Stilling, N. A. (1986). Preference, familiarity, and recognition after repeated brief exposure to random geometric shapes. American Journal of Psychology, 99, 403-415.

BoRNSTEIN, R. (1989). Exposure and affect: Overview and meta-analysis of research, 1968-1987. Psychological Bulletin, 106, 265-289.

Brickman, P., Redfield, J., Harrison, A. A., \& Crandall, R. (1972). Drive and predisposition as factors in the attitudinal effects of mere exposure. Journal of Experimental Social Psychology, 8, 31-44.

Chastel, A. (1971). Paris. New York: Holt, Rinehart \& Winston.

Cheetham, M. A. (2002). Kant, art, and art history. Cambridge: Cambridge University Press.

Clark, K. (1974). Another part of the wood. London: John Murray. Cutting, J., Wang, R. F., Flückiger, M., \& Baumberger, B. (1999). Human heading judgments and object-based motion information. $\mathrm{Vi}$ sion Research, 39, 1079-1105.

Daulte, F. (1959). Alfred Sisley: Catalogue raisonnéde l'oeuvre peint. Paris: Durand-Ruel. 
Daulte, F. (1971). Auguste Renoir: Catalogue raisonné de l'oeuvre peint: Vol 1. Figures 1860-1890. Lausanne: Durand-Ruel.

Distel, A. (1990). Impressionism: The first collectors. (B. PerroudBenson, Trans.). New York: Harry N. Abrams.

Distel, A. (Director) (1994). Gustave Caillebotte: 1848-1894 [Art exhibition]. Paris: Réunion des Musées Nationaux.

Elliott, R., \& Dolan, R. J. (1998). Neural response during preference and memory judgments for subliminally presented stimuli: A functional neuroimaging study. Journal of Neuroscience, 18, 4697-4704.

Ferguson, R. (1999). Can we still use the canon? Art Journal, 58, 4.

FEZZI, E. (1972). L'opera completa di Renoir [The complete works of Renoir]. Milan: Rizzoli Editore.

Fox, B. (1983, October 20). Video thrills the Hollywood star. New Scientist, 100, 203-208.

Gibson, J. J. (1947). Motion picture testing and research (Army Air Force Aviation Psychology Research Rep. 7). Washington, DC: U.S. Government Printing Office.

Goodman, N. (1972). Problems and projects. Indianapolis, IN: BobbsMerrill.

Guillory, J. (1990). Canon. In F. Lentrichhia \& T. McLaughlin (Eds.), Critical terms for literary study (pp. 233-262). Chicago: University of Chicago Press.

GuILloRY,J. (1993). Cultural capital: The problem with literary canon formation. Chicago: University of Chicago Press.

Hallberg, R. von (ED.) (1984). Canons. Chicago: University of Chicago Press.

Harrison, A. A. (1977). Mere exposure. In L. Berkowitz (Ed.), Advances in experimental social psychology (Vol. 10, pp. 39-83). New York: Academic Press.

HARrison, A. A., \& ZaJonc, R. B. (1970). Effects of frequency and duration of exposure on response competition and affect ratings. Journal of Psychology, 75, 163-169.

HAYWARD GALlERY (1985). Renoir. Catalog of the exhibit at the Hayward Gallery, London, 30 June-21 August 1985, Galérie Nationale de Grand Palais, Paris, 14 May-2 September 1985, Museum of Fine Arts, Boston, 9 October-5 January, 1986.

JAmot, P., \& Wildenstein, G. (1932). Edouard Manet (Vols. 1 and 2). Paris: Les Beaux-arts.

JoSEPh, J. E., \& Proffitt, D. R. (1996). Semantic versus perceptual influences of color on object recognition. Journal of Experimental Psychology: Learning, Memory, \& Cognition, 22, 407-429.

KAnT, I. (1952). Critique of aesthetic judgment. (J. Meredith, Trans.) Oxford: Oxford University Press, Clarendon Press. (Original work published 1794)

Klinger, M. R., \& Greenwald, A. (1994). Preferences need no inferences? The cognitive basis of unconscious mere exposure effects. In P. M. Niedenthal \& S. Kitayama (Eds.), The heart's eye: Emotional influences in perception and attention (pp. 67-85). San Diego: Academic Press.

Kozlowski, L. T., \& Cutting, J. E. (1977). Recognizing the sex of a walker from a dynamic point-light display. Perception \& Psychophysics, 21, 575-580.

Kunst-Wilson, W. R, \& Zajonc, R. B. (1980). Affective discrimination of stimuli that cannot be recognized. Science, 207, 557-558.

Lemoisne, P. A. (1946). Degas et son oeuvre (Vols. 1-4). Paris: Arts et Métiers Graphiques.

Marcus, M. G., \& HaKmiller, K. L. (1975). Effects of frequency, duration of study trials and total duration of exposure on affective judgments. Psychological Reports, 37, 195-200.

Marrinan, M. (2002). Caillebotte as a professional painter: From Studio to the public eye. In N. Broude (Ed.), Gustave Caillebotte and the fashioning of identity in Impressionist Paris (pp. 21-65). New Brunswick, NJ: Rutgers University Press.

MeAD, K. H. (Director) (1974). The Impressionists and the salon (1874-1886) [Art exhibition]. Riverside, CA: Regents of the University of California.

Monahan, J. L., Murphy, S. T., \& Zajonc, R. B. (2000). Subliminal mere exposure: Specific, general, and diffuse effects. Psychological Science, 11, 462-466.

Moreland, R. L., \& Zajonc, R. B. (1977). Is stimulus recognition a necessary condition for the occurrence of exposure effects? Journal of Social \& Personality Psychology, 35, 191-199.
Moxey, K. (1994). The practice of theory: Poststructuralism, cultural politics, and art history. Ithaca, NY: Cornell University Press.

MusÉe D'Orsay (1990). Catalogue sommaire illustré des peintures (Vols. 1 and 2). Paris: Réunion des Musées Nationaux.

Nord, P. (2000). Impressionists and politics. London: Routledge.

Oliva, A., \& Schyns, P. G. (2000). Diagnostic colors mediate scene recognition. Cognitive Psychology, 41, 176-210.

Pirsig, R. (1974). Zen and the art of motorcycle maintenance. New York: Morrow.

Pissarro, L.-R, \& Venturi, L. (1939). Camille Pissarro - son art son oeuvre (Vols. 1 and 2). Paris: Paul Rosenberg.

REWALD, J. (1946). The history of Impressionism. New York: Museum of Modern Art.

Rewald, J. (1996). The paintings of Paul Cézanne: A catalogue raisonné (Vols. 1 and 2). New York: Harry N. Abrams.

RoEDIGER, H. L., III (1990). Implicit memory: Retention without remembering. American Psychologist, 45, 231-246.

Rosch, E. H. (1973). Natural categories. Cognitive Psychology, 4, 328350.

Rosenberg, J. (1967). On quality in art: Criteria of excellence, past and present. Princeton, NJ: Princeton University Press.

Saltzman, C. (1998). Portrait of Dr. Gachet. New York: Penguin.

SAssoon, D. (2001). Becoming Mona Lisa. New York: Harcourt.

SCHACTER, D. L. (1987). Implicit memory: History and current status. Journal of Experimental Psychology: Learning, Memory, \& Cognition, 13, 501-518.

Seamon, J. G. , Brody, N., \& Kauff, D. M. (1983). Affective discrimination of stimuli that are not recognized: II. Effect of delay between study and test. Bulletin of the Psychonomic Society, 21, 187-189.

Seamon, J. G., \& Delgado, M. R. (1999). Recognition memory and affective preference for depth-rotated solid objects: Part-based structural descriptions may underlie the mere exposure effect. Visual Cognition, 6, 145-164.

Seamon, J. G., Williams, P. C., Crowley, M. J., Kim, I. J., Langer, S. A., Orne, P. J., \& Wishengrad, D. L. (1995). The mere exposure effect is based on implicit memory: Effects of stimulus type, encoding conditions, and number of exposures on recognition and affects judgments. Journal of Experimental Psychology: Learning, Memory, \& Cognition, 21, 711-721.

Shikes, R. E., \& Harper, P. (1980). Pissarro: His life and work. New York: Horizon.

Smith, E. R. (1998). Mental representation and memory. In D. T. Gilbert, S. T. Fiske, \& G. Lindzey (Eds.), The handbook of social psychology (4th ed., pp. 391-445). Boston: McGraw-Hill.

SQuire, L. R. (1992). Memory and the hippocampus: A synthesis of findings with rats, monkeys, and humans. Psychological Review, 99, 195-231.

VANBESELEARE,N. (1983). Mere exposure: A search for an explanation. In W. Doise \& S. Moscovici (Eds.), Current issues in European social psychology (Vol. 1, pp. 239-278). London: Cambridge University Press.

Varnedoe, K. (1987). Gustave Caillebotte. New Haven, CT: Yale University Press.

Venturi, L. (1936). Cézanne, son art, son oeuvre (Vols. 1 and 2). Paris: Paul Rosenberg.

WADLEY, N. (ED.) (1987). Renoir: A retrospective. New York: Macmillan.

White, B. E. (1984). Renoir: His life, art, and letters. New York: Harry N. Abrams.

Wildenstein, D. (1974-1985). Claude Monet: Biographie et catalogue raisonné (Vols. 1-5). Paris: La Bibliothèque des Arts.

Winkielman, P., Zajonc, R. B., \& Schwarz, N. (1997). Subliminal affective priming resists attributional interventions. Cognition \& Emotion, 11, 433-465.

Woodford, S. (1983). Looking at pictures. Cambridge: Cambridge University Press.

Wurm, L. H., Legge, G. E., Isenberg, L. M., \& Luebker, A. (1993). Color improves object recognition in normal and low vision. Journal of Experimental Psychology: Human Perception \& Performance, 19, 899-911.

ZaJonc, R. B. (1968). Attitudinal effects of mere exposure. Journal of Personality \& Social Psychology, 9, 1-27. 
ZAJONC, R. B. (1970, February). Brainwash: Familiarity breeds comfort. Psychology Today, 4, 33-35, 60-62.

ZAJONC, R. B. (1980). Feeling and thinking: Preferences need no inferences. American Psychologist, 35, 151-175.

Zajonc, R. B. (2001). Mere exposure: A gateway to the subliminal. Current Directions in Psychological Science, 10, 224-228.

Zajonc, R. B., Crandall, R., Kail, R. V., \& Swap, W. (1974). Effects of extreme exposure frequencies on different affective ratings of stimuli. Perceptual \& Motor Skills, 38, 667-678.

Zajonc, R. B., Shaver, P., Tavris, C., \& van Kreveld, D. (1972). Exposure, satiation, and stimulus discriminability. Journal of Personality \& Social Psychology, 21, 270-280.

\section{NOTES}

1. Caillebotte left no records concerning the accumulation of his collection. He seems to have acquired 57 of the 66 artworks used here in the 7 years up to and including 1882, and probably only 9 in the 12 years thereafter. Among the latter, 3 were gifts ( 1 from Monet and 2 from Renoir), and 6 were purchased (3 Sisleys and 3 Manets). The Manets were purchased in 1884 at the studio sale to support his widow. Nonetheless, in 1882, Caillebotte retired from Paris and removed himself from new developments in art. In that year, Georges Seurat had yet to paint his first divisionist (pointilliste) painting; Paul Gauguin was still a stockbroker; Vincent Van Gogh, although a painter for 2 years (having given up teaching and mission work), was still 4 years away from moving to Paris; and Henri Toulouse-Lautrec was a teenage art student.

2. As a part of a larger project, I inspected 30 books on Impressionism published over the 20th century and found that these seven artists had works appearing in at least 29 of them. The next most frequent artists were Berthe Morisot (25), Mary Cassatt (22), Georges Seurat (21), Frédéric Bazille (19), Paul Gauguin (18), Henri Toulouse-Lautrec (16), Gustave Caillebotte (14), and Vincent Van Gogh (13).

3. Much has been made of this quote, and it takes many different forms. Shikes and Harper (1980), for example, cited it as including Manet rather than Monet.

4. Most recent research on mere exposure methodologically allies itself with subliminal perception. That is, stimuli are presented briefly and then masked so that observers cannot report what they have seen but can be shown to have processed it through results of priming or preference (e.g., Kunst-Wilson \& Zajonc, 1980; Monahan, Murphy, \& Zajonc, 2000; Moreland \& Zajonc, 1977; Seamon, Brody, \& Kauff, 1983). These results are interesting and important, but from the perspective of this article, subliminal perception is a laboratory phenomenon used to mimic the processes in real life perception-inattention and forgetting over the long haul. Otherwise, it can have no general interest. Thus, in this context, I am less interested in alternative theories that may explain mere subliminal exposure (e.g., Bonnano \& Stilling, 1986; Klinger \& Greenwald, 1994; Smith, 1998; Winkielman, Zajonc, \& Schwarz, 1997; Zajonc, 2001) than in the more general phenomenon itself.

5. Once found, the images not appearing in Distel (1994) were checked for their provenance (ownership history), to be sure they had been Caillebotte's. In addition, despite 20 months search in libraries and on the Internet, I was unable to find five of these works. Mention of these appeared without images in Distel (1994) or in images in the catalogue raisonné of each painter. They include one Monet, three Pissarros, and one Sisley-all listed at the end of the Appendix.

6. A catalogue raisonné assembles and illustrates, typically chronologically, the entire corpus of an artist's work, often with additional material, such as correspondence. Inevitably, it has inconsistencies and errors revealed by later research. In this context, dating works is a particular problem with Cézanne. Thus, Rewald's (1996) compendium was a necessary revision of Venturi (1936). Similarly, there are dating problems with Degas. For example, Distel (1994) noted that Image 14c (Danseuse espagnol, "Spanish dancer") was purchased by Caillebotte before May 1879, yet Lemoisne (1946) listed it as having been painted in 1880. Some catalogues raisonnés, such as that of Manet (Jamot \& Wildenstein, 1932), occasionally list images thematically (e.g., Image Pair 17), rather than chronologically.

7. Fox (1983), from Kodak data and in the context of predictions about high-definition TV, reported that $35-\mathrm{mm}$ film has a digital resolution of about $2,500 \times 1,800$ pixels, or $4.5 \mathrm{MB}$. The files used in Study 1 were about $65 \%$ of that resolution along one dimension.

8. Renoir's Bal du Moulin de la Galette is almost surely the most reproduced of all Impressionist paintings. For example, in one Paris guidebook (Chastel, 1971), I found only two paintings representing what might be found in the city-Mona Lisa and Bal du Moulin de la Galette. In turn, the Mona Lisa (also La Joconde) is often regarded as the world's most famous painting (Sassoon, 2001) or, if one counts Michelangelo's ceiling of the Sistine Chapel, the second most famous (September 24, 1995, London Sunday Times, The Culture, Section 10, p. 29). However, the latter assessment was made not long after the Sistine ceiling was cleaned, and with understandable effects of its accompanied media coverage.

9. Inspecting each entry is necessary: "Monet" is also one of the middle names of both Lamarck and Lavoisier, as well as the Russian word for money; Pierre-Auguste Renoir must be distinguished from his younger son the filmmaker, Jean Renoir (except in the latter's book about the former); Camille Pissarro must be separated from his sons, particularly Lucien who was also an artist (but who also wrote of his father); and there are several authors named Sisley, as well as an Italian fashion line.

10. To exclude Postimpressionism is to exclude some descriptions of the work of Cézanne and, to a lesser degree, Degas. However, these works were composed after Caillebotte stopped collecting in 1882. Pissarro also had a Neoimpressionist (pointilliste) period, but this too occurred after Caillebotte actively collected.

11. The Orsay comparison images appeared a mean of 39.5 times and the non-Orsay comparisons 25.1 times. Note, however, than many more of the comparison images (27) were from other museums than the Caillebotte images (10).

12. There was no reliable effect of color versus black and white in the counts of images in the Cornell books that effected either recognition or preference, but the effect reported above concerns the presence of color versus black and white in the stimuli as presented to the viewers.

13. The six additional Caillebotte paintings were: Déjeuner ("Luncheon," 1876, private collection), Portraits à la campagne ("Country portraits," 1876, Musée Baron Gérard, Bayeux, France), Le pont de l'Europe ("The Europe bridge," Paris, 1876, Musée du Petit Palais, Genève, Switzerland), Peintres en bâtiment ("House painters," 1877, private collection), Rue de Paris; temps de pluie ("Paris street, rainy weather," 1877, Art Institute of Chicago), and Boulevard vu d'en haut ("Boulevard viewed from above," 1880, private collection). Reference citations for these images are Bérhaut (1994)\#37, 40, 49, 53, 57, and 154 , respectively.

14. This figure was determined through analysis of the catalogues raisonnés of the seven "major" Impressionists and the holdings catalog of the Musée d'Orsay (Musée d'Orsay, 1990).

15. It is often noted that the effects of mere exposure may even decline with experience repeated very many times (e.g., Bornstein, 1989; Zajonc, Crandall, Kail, \& Swap, 1974). This may well be true in laboratory situations or in the real world with massed practice, but it is not clearly the case with exposures distributed over years, even decades. 


\section{APPENDIX \\ The Caillebotte and Comparison Images,}

Their Dates (If Known), Their Locations (If Known), and Their Reference Citations

From the Caillebotte Legacy and Collection

Comparison Images

Caillebotte

1. Les Raboteurs de parquet

"The floor strippers"

1875, Musée d'Orsay (RF 2718)

Bérhaut (1994) \#34; Figure 1A

2. Vue de toits, effet de neige

"Snow-covered roofs in Paris"

1878, Musée d'Orsay (RF 876)

Bérhaut (1994) \#96

\section{Cézanne}

3. Au bord de l'étang or Scène champêtre "Couples relaxing by a pond" or "The pond" 1876-1877, Museum of Fine Arts, Boston Venturi (1936) \#232, Rewald (1996) \#244

4. Baigneurs au repos, III

"Bathers at rest"

1876-1877, Barnes Foundation

Venturi (1936) \# 276, Rewald (1996) \#261

5. Fleurs dans un vase rococo or Vase de fleurs

"Flowers in a rococo vase" 1876, National Gallery of Art, DC Venturi (1936) \#222, Rewald (1996) \#265

6. Cour de ferme à Auvers

"Farmyard at Auvers"

1879-1880, Musée d'Orsay (RF 2760)

Venturi (1936) \#326,

Rewald (1996) \#389; Figure 1C

7. Le Golfe de Marseille, vu de l'Estaque*

"Estaque"

1878-1880, Musée d'Orsay (RF 2761)

Venturi (1936) \#428, Rewald (1996) \#390

Degas

8. Femmes à la terrase d'un café, le soir or Un Café, boulevard Hausmann

"Women outside a cafe in the evening" 1877, Musée d'Orsay (RF 12257)

Lemoisne (1946) \#419; Figure 1E

9. Choristes or Les Figurants

"The chorus" or "The supernumeraries"

1876-1877, Musée d'Orsay (RF 12259)

Lemoisne (1946) \#420

10. Femme sortant du bain

"Woman leaving the bath"

1876-1877, Musée d'Orsay (RF 12255)

Lemoisne (1946) \#422

11. La Leçon de danse

"Portrait of a dancer at her lesson"

1879, Metropolitan Museum of Art, New York Lemoisne (1946) \#450

12. L'Étoile (Danseuse sur la scène)

"Ballet (The star)"

1876-1878, Musée d'Orsay (RF 12258)

Lemoisne (1946) \#491
Les Raboteurs de parquet (petit version)

"The floor strippers (small version)"

1876, private collection, Paris

Bérhaut (1994) \#35; Figure 1B

Rue Halévy, vue d'un sixième étage

"Rue Halévy, view from the 7th floor"

1878 , private collection

Bérhaut (1994) \#100

\section{Le Déjeuner sur l'herbe}

"The picnic" or "Luncheon on the grass" 1876-1877, Musée de l'Orangerie

Venturi (1936) \#238, Rewald (1996) \#287

Les cinq baigneurs

"The five bathers"

1875-1877, Musée d'Orsay (RF 1982-42)

Venturi (1936) \#268, Rewald (1996) \#254

Bouquet au petit Delft

"Flowers in a Delft vase"

1873, Musée d'Orsay (RF 1951-33)

Venturi (1936) \#183, Rewald (1996) \#227

La Maison du pendu, Auvers-sur-Oise

"House of the hanged man"

1873, Musée d'Orsay (RF 1970)

Venturi (1936) \#133,

Rewald (1996)\#202; Figure 1D

La Baie de l'Estaque vue de l'est

"The bay of Estaque looking east"

1878-1879, Memorial Art Gallery,

University of Rochester, NY

Venturi (1936) \#408, Rewald (1996) \#394

Dans un café or L'Absinthe

"The absinthe drinker"

1876, Musée d'Orsay (RF 1984)

Lemoisne (1946) \#393; Figure 1F

Danseuse au bouquet saluant

"Dancer with bouquet, bowing"

1877, Musée d'Orsay (RF 4039)

Lemoisne (1946) \#474

Après le bain

"Nude woman drying her feet"

1885-1886, Musée d'Orsay (RF 4045)

Lemoisne (1946) \#874

Danseuses à la barre

"Dancers practicing at the bar"

1876-1877, Metropolitan Museum of Art, New York

Lemoisne (1946) \#408

Danseuse tenant un bouquet à la main

"Arabesque"

1877, Musée d'Orsay (RF 4039)

Lemoisne (1946) \#418 
APPENDIX (Continued)

13. Femme nue, accroupie, de dos "Squatting woman seen from the back" 1879, Musée d'Orsay (RF 12254)

Lemoisne (1946) \#547

14. Danseuse espagnol or Chanteuse de café-concert "Study for the bust of a ballet dancer" 1880, Musée d'Orsay (RF 12260) Lemoisne (1946) \#608

15. Danseuse nouant son brodequin "Seated dancer kneading her ankle" 1881-1883, Musée d'Orsay (RF 12271) Lemoisne (1946) \#658

Manet

16. Angelina "Angelina" 1865, Musée d'Orsay (RF 3664) Jamot and Wildenstein (1932) \#118

17. Les Courses ${ }^{\dagger}$

"The races"

1865, location unknown Jamot and Wildenstein (1932) \#204

18. Le Balcon

"The balcony" 1868-1869, Musée d'Orsay (RF 2772) Jamot and Wildenstein (1932) \#150; Figure $1 \mathrm{G}$

19. Croquet à Boulogne or La Partie de croquet

"The croquet game" 1868-1871, Woll family, private collection Jamot and Wildenstein (1932) \#197

Monet

20. Le Mont Riboudet à Rouen au printemps "Mt. Riboudet at Rouen in spring" 1872, private collection, U.S. Wildenstein (1974-1985) \#216

21. Régates à Argenteuil "Regattas at Argenteuil" 1872, Musée d'Orsay (RF 2778) Wildenstein (1974-1985) \#233

22. Le Déjeuner

"Luncheon in the garden" 1873, Musée d'Orsay (RF 2774) Wildenstein (1974-1985) \#285

23. Un Coin d'appartement "Apartment interior" 1875, Musée d'Orsay (RF 2776) Wildenstein (1974-1985) \#365

24. Les Tuileries (esquisse) "The Tuileries" 1875, Musée d'Orsay (RF 2705) Wildenstein (1974-1985) \#403

25. La Plaine de Gennevilliers or La Plaine d'Argenteuil "The plain near Gennevilliers" 1877, Fogg Art Museum, Harvard Wildenstein (1974-1985) \#437

\section{Le Tub}

"Woman bathing in a shallow tub" 1886, Musée d'Orsay (RF 4046) Lemoisne (1946) \#872

Le Café-concert

"At the Café des Ambassadeurs" 1885, Musée d'Orsay (RF 4041)

Lemoisne (1946) \#814

L'Attente

"Dancer and woman with a black umbrella, waiting" 1882, Getty Museum, Malibu, CA

Lemoisne (1946) \#698

Georges Clemençeau

"Georges Clemençeau"

1879-1880, Musée d'Orsay (RF 2641)

Jamot and Wildenstein (1932) \#372

Courses à Longchamps ${ }^{\dagger}$

"At the races"

1875, National Gallery, Washington

Jamot and Wildenstein (1932) \#205

Le Déjeuner à l'atelier

"Luncheon in the studio"

1868, Neue Pinakothek, Munich

Jamot and Wildenstein (1932) \#149; Figure 1H

Plage avec personnages

"On the beach at Boulogne"

1869, Virginia Museum of Art, Richmond

Jamot and Wildenstein (1932)\#166

Vue de plaine à Argenteuil

"View of the plain at Argenteuil"

1872, Musée d'Orsay (MNR 855)

Wildenstein (1974-1985) \#220

Voilier au Petit-Gennevilliers

"Sailboat at Petit-Gennevilliers"

1874, Lucille Ellis Simon Collection, USA

Wildenstein (1974-1985) \#336

Femmes au jardin

"Women in the garden"

1866, Musée d'Orsay (RF 2773)

Wildenstein (1974-1985) \#67

Coind'atelier

"Corner of a studio"

1861, Musée d'Orsay (MNR 136)

Wildenstein (1974-1985) \#6

La Débâcle

"Ice break up"

1880, Museum of Art, University of Michigan

Wildenstein (1974-1985) \#565

Vétheuil, vu de Lavacourt

"Vétheuil, view from Lavacourt"

1879, Musée d'Orsay (RF 1998)

Wildenstein (1974-1985) \#528 
APPENDIX (Continued)

26. La Gare Saint-Lazare

"St. Lazare train station, Paris"

1877, Musée d'Orsay (RF 2775)

Wildenstein (1974-1985) \#438; Figure 2A

27. La Gare Saint-Lazare: sous le pont de l'Europe

"Gare Saint-Lazare: exterior view" or "Pont de Rome"

1877 , private collection

Wildenstein (1974-1985) \#447

28. La Gare Saint-Lazare à l'extérieur, le signal "The Gare Saint-Lazare, the signal" 1877, Landesmuseum, Hannover Wildenstein (1974-1985) \#448

29. Pommiers, Vétheuil

"Apple trees, Vétheuil"

1878, Wesley M. Dixon Collection, U.S. Wildenstein (1974-1985) \#490

30. L'Église de Vétheuil, neige "The church at Vétheuil, snow" 1878-1879, Musée d'Orsay (RF 3755) Wildenstein (1974-1985) \#506

31. Pruniers en fleurs or Poiriers en fleurs

"Blossoming plum trees" or "Blossoming pear trees"

1879 , location unknown Wildenstein (1974-1985) \#519

32. Le Givre

"Hoarfrost (Vétheuil)"

1880, Musée d'Orsay (RF 2706)

Wildenstein (1974-1985) \#555

33. Chrysanthèmes rouges

"Red chrysanthemums"

1880, location unknown

Wildenstein (1974-1985) \#635

34. La Seine entre Vétheuil et La Roche Guyon "The Seine between Vétheuil and

La Roche Guyon"

1881, private collection, France

Wildenstein (1974-1985) \#674

35. Les rochers de Belle-île

"The rocks of Belle-Isle"

1886, Musée d'Orsay (RF 2777)

Wildenstein (1974-1985) \#1100

Pissarro

36. Louveciennes

"Louveciennes"

1871 , private collection, Paris

Pissarro and Venturi (1939) \#123

37. Le Lavoir, Pontoise

"The washhouse at Bougival"

1872, Musée d'Orsay (RF 2732)

Pissarro and Venturi (1939)\#175

38. Paysage avec rochers, Montfoucault "Landscape with rocks, Montfoucault" 1874 , private collection, Paris Pissarro and Venturi (1939) \#282
La Gare Saint-Lazare, l'arrivée d'un train

"Gare Saint-Lazare, the arrival of a train" 1877, Fogg Art Museum, Harvard Wildenstein (1974-1985) \#439; Figure 2B

Le Pont de l'Europe, gare Saint-Lazare

"The Pont de l'Europe" 1877, Musée Marmottan, Paris Wildenstein (1974-1985) \#442

Les Voies à la sortie de la gare Saint-Lazare "The tracks in front of the Gare Saint-Lazare" 1877, private collection, Japan Wildenstein (1974-1985) \#445

Paysage, Vétheuil

"Landscape, Vétheuil"

1879, Musée d'Orsay (RF 2623)

Wildenstein (1974-1985) \#1986

Vétheuil l'hiver

"Vétheuil, winter"

1879, Frick Gallery, New York

Wildenstein (1974-1985) \#507

Lilas, temps gris

"Resting under the lilacs"

or "Lilacs, gray weather"

1972-1973, Musée d'Orsay (RF 1680)

Wildenstein (1974-1985) \#203

Vétheuil dans le brouillard

"Vétheuil in the mist"

1879, Musée Marmottan, Paris

Wildenstein (1974-1985) \#518

Chrysanthèmes

"Chrysanthemums"

1878, Musée d'Orsay (RF 1951-36)

Wildenstein (1974-1985) \#492

Les Glaçons or Débâcle sur la Seine

"The ice-floes"

1880, Musée d'Orsay (RF 1965-10)

Wildenstein (1974-1985) \#567

Tempêtes, Côtes de Belle-Île

"Storm at Belle-Isle"

1886, Musée d'Orsay (RF 3163 )

Wildenstein (1974-1985) \#1116

Entrée du village de Voisins

"Entrance to the village of Voisins"

1872, Musée d'Orsay (RF 2456)

Pissarro and Venturi (1939) \#141

Pontoise, Côte de l'Oise

"Pontoise, banks of the Oise"

1872, Getty Museum, Malibu

Pissarro and Venturi (1939) \#182

Côteau de l'Hermitage, Pontoise

"Hill at the Hermitage, Pontoise"

1873, Musée d'Orsay (RF 1983-8)

Pissarro and Venturi (1939) \#209 
APPENDIX (Continued)

39. Le Labourer

"The plowman"

1876, private collection, Paris

Pissarro and Venturi (1939) \#340

40. Jardin en fleurs, Pontoise

"Garden in bloom, Pontoise"

1876, private collection, Paris

Pissarro and Venturi (1939) \#350

41. La Moisson à Montfoucault

"Harvest at Montfoucault"

1876, Musée d'Orsay (RF 3756)

Pissarro and Venturi (1939) \#364

42. Sous bois avec une femme assise

"In the woods"

1876, private collection, Paris

Pissarro and Venturi (1939) \#371

43. Les Toits rouges, coin du village, effet d'hiver "The red roofs"

1877, Musée d'Orsay (RF 2735)

Pissarro and Venturi (1939) \#384; Figure 2C

44. Printemps à Pontoises, potager et arbres en fleurs

"Orchard with flowering fruit trees, Pontoise"

1877, Musée d'Orsay (RF 2733)

Pissarro and Venturi (1939) \#387

45. Les Seigles, Pontoise, côte des Mathurins or Les Orges

"Rye fields, Pontoise, seen from the Mathurins" 1877, private collection, Japan

Pissarro and Venturi (1939) \#406

46. Chemin sous-bois, en été

"Path through the woods"

1877, Musée d'Orsay (RF 2731)

Pissarro and Venturi (1939) \#416

47. Lisière de bois or Clairière

"Edge of the woods"

1878, private collection, Paris

Pissarro and Venturi (1939) \#455

48. Chemin montant à travers champs. Côte des Grouettes, Pontoise

"Path across the fields"

1879, Musée d'Orsay (RF 2736)

Pissarro and Venturi (1939) \#493

49. La Brouette, verger

"The wheelbarrow"

1881, Musée d'Orsay (RF 2734)

Pissarro and Venturi (1939) \#537

Renoir

50. La Liseuse

"Girl reading"

1874-1876, Musée d'Orsay (RF 3757)

Daulte (1971) \#106, Fezzi (1972)\#202,

Wadley (1987) \#36

51. La Place Saint-Georges

"St. George Place"

$\sim 1875$, private collection

Distel (1994) p.65, fig. 55
Paysage à Chaponval

"Chaponval landscape"

1880, Musée d'Orsay (RF 1937-51)

Pissarro and Venturi (1939) \#509

L'Hermitage à Pontoise

"The Hermitage, Pontoise"

1872, private collection, Japan

Pissarro and Venturi (1939) \#529

La Meule, Pontoise

"The haystack, Pontoise"

1873, private collection, Paris

Pissarro and Venturi (1939) \#223

Le Petit pont, Pontoise

"Little bridge, Pontoise"

1875, Kunsthalle, Mannheim

Pissarro and Venturi (1939) \#300

La Côte des boeufs à Pontoise

"La Côte des Boeufs, the Hermitage"

1877, National Gallery, London

Pissarro and Venturi (1939) \#380; Figure 2D

Verger en fleurs, Louveciennes

"Orchard in blossom, Louveciennes"

1872, National Gallery, Washington

Pissarro and Venturi (1939) \#153

Gardeuse de vache sur la route du Chou, Pontoise "A cowherd at Pontoise"

1874, Metropolitan Museum of Art, New York

Pissarro and Venturi (1939) \#260

Au repos sous-bois, Pontoise

"Resting in the woods, Pontoise"

1878, Kunsthalle, Hamburg

Pissarro and Venturi (1939) \#466

Le Châlet, la maison rose

"The chalet, the pink house"

1870, Musée d'Orsay (RF 1937-58)

Pissarro and Venturi (1939) \#82

Femme dans un clos

"Woman in an enclosure, spring sunshine in an Eragny field"

1887, Musée d'Orsay (RF 1937-47)

Pissarro and Venturi (1939) \#709

Automne, l'étang de Monfoucault

"Autumn, Monfoucault pond"

1875 , private collection, Paris

Pissarro and Venturi (1939) \#329

L'Amazone

"Madame Darras"

1873, Musée d'Orsay (RF 1965-11)

Daulte (1971) \#93, Fezzi (1972)\#103

La Mosquée, fête arabe

"The mosque" or "Arab festival in Algiers"

1881, Musée d'Orsay (RF 1957-8)

Fezzi (1972) \#462, Hayward Gallery (1985) \#56 
APPENDIX (Continued)

52. Étude, torse, effet de soleil

"Torso of a woman in sunlight"

1875-1876, Musée d'Orsay (RF 2740)

Daulte (1971) \#201, Fezzi (1972) \#204,

Hayward Gallery (1985) \#36,

Wadley (1987)\#44

53. La Balançoire

"The swing"

1876, Musée d'Orsay (RF 2738)

Daulte (1971) \#202, Fezzi (1972) \#242,

Hayward Gallery (1985) \#39

54. Bal du Moulin de la Galette, Montmartre

"Ball at the Moulin de la Galette"

1876, Musée d'Orsay (RF 2740)

Daulte (1971) \#209, Fezzi (1972) \#249,

Hayward Gallery (1985) \#40; Figure 2E

55. Bords de Seine à Champrosay

"Banks of the Seine at Champrosay"

1876, Musée d'Orsay (RF 2737)

Fezzi (1972) \#256, Wadley (1987)\#43

56. Le Pont du chemin de fer à Châtou

"The railroad bridge at Châtou"

1881, Musée d'Orsay (RF 3758)

Fezzi (1972) \#470

57. Le Château des brouillards or Soleil couchant à Montmartre "The chateau of the mists"

(Renoir family home)

$\sim 1890$, private collection

Distel (1994) p. 65, Figure 56

58. Jeunes filles au piano $\$$

"Young girls at the piano"

1892, private collection, Paris

Hayward Gallery (1985) \#90

Sisley

59. Les Régates à Molesey

"Boat races at Molesey, near Hampton Court"

1874, Musée d'Orsay (RF 2787)

Daulte (1959) \#126; Figure 2G

60. Une Rue à Louveciennes

"A street in Louveciennes"

1876, Musée de Beaux-Arts, Nice

Daulte (1959) \#221 (deaccessioned

from Musée d'Orsay, RF 2783)

61. La Seine à Suresnes

The Seine at Suresnes" or

"The banks of the Seine"

1877, Musée d'Orsay (RF 2786)

Daulte (1959) \#267

62. Cour de ferme à Saint-Mammès

"Farmyard at Saint-Mammès"

1884, Musée d'Orsay (RF 2700)

Daulte (1959) \#544

63. Lisière de forêt au printemps

"Edge of the forest near Fontainbleau"

1885, Musée d'Orsay (RF 2784)

Daulte (1959) \#350
Nue or Torse d'Anna

"Female nude (Anna)"

1979, Pushkin Art Museum, Moscow

Daulte (1971) \#213, Fezzi (1972) \#250

La Tonnelle du Moulin de la Galette

"The arbor" or "The bower"

1875-1876, Pushkin Art Museum, Moscow

Daulte (1971) \#197, Fezzi (1972) \# 240

Le Déjeuner des canotiers

"Luncheon of the boating party"

1881, Phillips Collection, Washington

Daulte (1971) \#379, Fezzi (1972) \#468,

Hayward Gallery (1985) \#52; Figure 2F

Paysage de neige

"Snowy landscape"

1875, Musée de l'Orangerie, Paris

Hayward Gallery (1985) \#33, Wadley (1987) \#42

Femme avec parasol dans le jardin

"Woman with a parasol in the garden"

1873, Thyssen-Bornemisza Gallery, Madrid

Fezzi (1972)\#199, Wadley (1987)\#22

Chemin montant dans les hautes herbes

"Path winding through tall grass"

1876-1877, Musée d'Orsay (RF 2581)

Fezzi (1972)\#141, Wadley (1987)\#67

\section{La Leçon de piano}

"Piano lesson"

1889, Joslyn Art Museum, Omaha

Daulte (1971) \#561, Fezzi (1982) \#661,

Hayward Gallery (1985) \#84

Les régates à Hampton Court

"Boat races at Hampton Court"

1874, Sammlung E.G. Bührle, Zurich

Daulte (1959) \#125; Figure 2H

Un Coin de bois aux Sablons

"A corner of the woods, the Sablons"

1883, Musée d'Orsay (RF 2079)

Daulte (1959) \#502

Le Pont à Sèvres

"The bridge at Sèvres"

1877, National Gallery, Prague

Daulte (1959) \#262

Village de Voisins

"Village of Voisins"

1874, Musée d'Orsay (RF 2019)

Daulte (1959) \#142

À repos au bord du ruisseau

"Resting by a brook"

1872, Musée d'Orsay (RF 1693)

Daulte (1959) \#42 
APPENDIX (Continued)

64. Saint-Mammès

"Saint-Mammès"

1885, Musée d'Orsay (RF 2785)

Daulte (1959) \#629

65. Seine à Billancourt

"The Seine at Billancourt" undated, private collection Distel (1994) p. 67, Figure 63

66. Bords de la Seine, effet du soleil couchant "Banks of the Seine, sunset" undated, private collection Distel (1994), p.67, Figure 59

Caillebotte Images Not Found

\section{Monet}

Une colline rose (Vues de Vétheuil)

"A pink hill in Vétheuil"

undated, location unknown

not in Wildenstein (1974-1985)

Sisley

Station de bateaux à Auteuil

"Boat dock at Auteuil"

undated, location unknown

not in Daulte (1959)
Canal du Loing

"Loing canal"

1884, Musée d'Orsay (RF 1972-33)

Daulte (1959) \#522

La Seine à Bougival

"The Seine at Bougival"

1881, Musée d'Orsay (MNR 208)

Daulte (1959) \#90

Bateaux à l'écluse de Bougival

"Boats at the Bougival lock"

1873, Musée d'Orsay (RF 1690)

Daulte (1959) \#90

\author{
Pissarro \\ Coin de village - les choux \\ "Village corner - cabbages" \\ 1875, location unknown \\ Pissarro and Venturi (1939) \#312, \\ image not presented
}

La vallée en été, Pontoise

"The valley in summer, Pontoise" 1877, location unknown

Pissarro and Venturi (1939) \#407, image not presented

Sous-bois en automne, Pontoise

"In the autumn woods, Pontoise"

1879, location unknown

Pissarro and Venturi (1939) \#505, image not presented

*Cézanne's Image 7c is very similar to two others perhaps equally well known: One is in the New York Metropolitan Museum of Art (Venturi, 1936,\#625), and the other is in the Art Institute of Chicago (Venturi, 1936, \#626), both with the same name, "The gulf of Marseille, seen from Estaque." †Manet’s Image 17c was a study for Courses à Longchamps, 1867, Art Institute of Chicago (Jamot \& Wildenstein, 1932, \#202). Image 17n is a similar study, but done several years later. $\quad$ Renoir painted two versions of 54c. Caillebotte owned the original. For many years the smaller copy was on loan to the Metropolitan Museum of Art in New York (see Distel, 1990; White, 1984), but was sold at Christie's to Ryoei Saito for $\$ 78$ million in 1990 . The week before, Mr. Saito had purchased Van Gogh's "Portrait of Dr. Gachet" for \$82.5 million. Mr. Saito soon went bankrupt, and these two most expensive paintings ever sold (through mid 2003) are now probably in a Tokyo bank vault (Saltzman, 1998). \$Under commission from the French state, Renoir painted at least five versions of 58c. That chosen by the government is now in the Musée d'Orsay (RF 755), another in the Musée de l'Orangerie, a third in the Metropolitan Museum, and at least a fourth in a private collection (Hayward Gallery, 1985, pp. 261-263; Wadley, 1987).

(Manuscript received December 10, 2001; revision accepted for publication May 17, 2002.) 